Chapman University

Chapman University Digital Commons

Pharmacy Faculty Articles and Research

School of Pharmacy

2012

\title{
Melatonin Membrane Receptors in Peripheral Tissues: Distribution and Functions
}

Radomir M. Slominski

University of Tennessee

Russel J. Reiter

University of Tennessee

Natalia Schlabritz-Loutsevich

University of Tennessee

Rennolds S. Ostrom

Chapman University, rostrom@chapman.edu

Andrzej T. Slominski

University of Tennessee

Follow this and additional works at: http://digitalcommons.chapman.edu/pharmacy_articles

Part of the Amino Acids, Peptides, and Proteins Commons, Cell Biology Commons, and the Other Pharmacy and Pharmaceutical Sciences Commons

\section{Recommended Citation}

Radomir M. Slominski, Russel J. Reiter, Natalia Schlabritz-Loutsevitch, Rennolds S Ostrom and Andrzej T. Slominski. Melatonin Membrane Receptors in Peripheral Tissues: Distribution and Functions. Mol Cell Endocrin, 351:152-166, 2012.

This Article is brought to you for free and open access by the School of Pharmacy at Chapman University Digital Commons. It has been accepted for inclusion in Pharmacy Faculty Articles and Research by an authorized administrator of Chapman University Digital Commons. For more information,

please contact laughtin@chapman.edu. 


\section{Melatonin Membrane Receptors in Peripheral Tissues: Distribution and Functions}

\section{Comments}

NOTICE: this is the author's version of a work that was accepted for publication in Molecular and Cellular Endocrinology. Changes resulting from the publishing process, such as peer review, editing, corrections, structural formatting, and other quality control mechanisms may not be reflected in this document. Changes may have been made to this work since it was submitted for publication. A definitive version was subsequently published in Molecular and Cellular Endocrinology, volume 351, in 2012. DOI: 10.1016/j.mce.2012.01.004

The Creative Commons license below applies only to this version of the article.

\section{Creative Commons License}

\section{(c) 1 (1) 90}

This work is licensed under a Creative Commons Attribution-Noncommercial-No Derivative Works 4.0 License.

\section{Copyright}

Elsevier 


\title{
Melatonin membrane receptors in peripheral tissues: Distribution and functions
}

\author{
Radomir M. Slominski ${ }^{a, b}$, Russel J. Reiter ${ }^{c}$, Natalia Schlabritz-Loutsevitch ${ }^{d}$, Rennolds S. \\ Ostrom $^{\mathrm{a}}$, and Andrzej T. Slominski ${ }^{\mathrm{b}, \mathrm{e},{ }^{*}}$ \\ aDepartment of Pharmacology, University of Tennessee Health Science Center, Memphis, TN \\ 38163, United States \\ ${ }^{b}$ Department of Pathology and Laboratory Medicine, University of Tennessee Health Science \\ Center, Memphis, TN 38163, United States \\ 'Department of Cellular \& Structural Biology, UT Health Science Center, San Antonio, TX \\ 78229-3900, United States \\ dDepartment of Obstetrics and Gynecology, University of Tennessee Health Science Center, \\ Memphis, TN 38163, United States \\ eDivision of Dermatology, Department of Medicine, University of Tennessee Health Science \\ Center, Memphis, TN 38163, United States
}

\begin{abstract}
Many of melatonin's actions are mediated through interaction with the G-protein coupled membrane bound melatonin receptors type 1 and type 2 (MT1 and MT2, respectively) or, indirectly with nuclear orphan receptors from the ROR $\alpha$ /RZR family. Melatonin also binds to the quinone reductase II enzyme, previously defined the MT3 receptor. Melatonin receptors are widely distributed in the body; herein we summarize their expression and actions in non-neural tissues. Several controversies still exist regarding, for example, whether melatonin binds the ROR $\alpha /$ RZR family. Studies of the peripheral distribution of melatonin receptors are important since they are attractive targets for immunomodulation, regulation of endocrine, reproductive and cardiovascular functions, modulation of skin pigmentation, hair growth, cancerogenesis, and aging. Melatonin receptor agonists and antagonists have an exciting future since they could define multiple mechanisms by which melatonin modulates the complexity of such a wide variety of physiological and pathological processes.
\end{abstract}

\section{Keywords}

Melatonin; Receptors; Peripheral organs; Regulation; Skin

\section{Introduction to melatonin, its biosynthesis and metabolism}

Melatonin ( $N$-acetyl-5-methoxytrypamine) has been known for over 50 years when Lerner et al. characterized and isolated this indolamine from the bovine pineal gland and found that it caused the lightening of the frog skin (Lerner et al., 1959), thus, identifying the depigmenting factor first described in 1917 by McCord and Allen (Lerner, 1960).

(C) 2012 Published by Elsevier Ireland Ltd.

Corresponding author at: Department of Pathology and Laboratory Medicine, University of Tennessee Health Science Center, 930 Madison Avenue, Suite 5000, Memphis, TN 38163, United States. Tel.: +1 901448 3741. aslominski@uthsc.edu (A.T. Slominski). 
Accordingly, Lerner along with his co-workers were the first to define chemical structure of this compound as $N$-acetyl-5-methoxytrypamine and to show that it acts as an antagonist of the $\alpha$-melanocyte stimulating hormone ( $\alpha$-MSH) (Lerner et al., 1960).

It took some time thereafter to establish the biosynthetic pathway of melatonin. The synthesis of melatonin is a multistep process, which starts with hydroxylation of aromatic amino acid L-tryptophan to 5-hydroxytryptophan catalyzed by tryptophan hydroxylase (TPH, EC 1.14.16.4), which uses 6-tetrahydropterin (6-BH4) as an essential co-factor for this reaction (McIsaac and Page, 1959; Schallreuter et al., 1994). 5-Hydroxytryptophan is then converted to serotonin (5-hydroxytryptamine) by the aromatic amino acid decarboxylase (AAD, EC 4.1.1.28) (Lovenberg et al., 1962). Serotonin is subsequently converted to $N$-acetylserotonin by the enzyme arylalkylamine $N$-acetyltransferase (AANAT, EC 2.3.1.87) (Lovenberg et al., 1967). The final step of melatonin synthesis is the conversion of $\mathrm{N}$-acetylserotonin to melatonin by hydroxyindole- $O$-methyl transferase (HIOMT, EC 2.1.1.4) (Weissbach, 1960). The correct designation of HIOMT is serotonin $N$ acetyltransferase (ASMT) and is described in great detail by Stehle et al. (2011). The biosynthetic pathway of melatonin is shown in Fig. 1.

Both the AANAT and HIOMT have been considered the rate limiting steps in melatonin production, however Liu and Borjigin have found that HIOMT is not the rate-limiting enzyme in melatonin synthesis (Brydon et al., 1999; Liu and Borjigin, 2005; Reiter, 1991c). Also, it has been documented that serotonin can also be acetylated to $N$-acetylserotonin by an alternative enzyme, most likely arylamine $N$-acetyltransferase (NAT1) (Liu and Borjigin, 2005; Slominski et al., 2005a, 2003).

There are three major pathways of melatonin degradation: (1) the classical hepatic degradation pathway that generates 6-hydroxymelatonin (Facciola et al., 2001; Reiter, 1991c), (2) the alternative indolic pathway that produces 5-methoxyindole acetic acid (5MIAA) or 5-methoxytryptophol (5-MTOL) (Grace et al., 1991; Rogawski et al., 1979), and (3) the kynuric pathway that produces $N 1$-acetyl- $N 2$-formyl-5-methoxykynuramine (AFMK) (Hardeland et al., 1993; Hirata et al., 1974; Slominski et al., 2008; Tan et al., 2007). In the classical melatonin degradation pathway, the liver CYP P450 enzymes CYP1A1, CYP1A2, and CYP1B1 metabolize melatonin to 6-hydroxymelatonin (Ma et al., 2005). This product is then conjugated with either sulfate or glucuronide and then secreted in the urine (Arendt, 1988). In the liver, melatonin can also be demethylated to $N$-acetylserotonin by either CYP2C19 or CYP1A (Facciola et al., 2001).

The alternative indolic pathway involves melatonin being metabolized to 5methoxytryptamine by melatonin deacetylase (Grace et al., 1991; Rogawski et al., 1979; Slominski et al., 2005a). 5-Methoxytryptamine is then converted by monoamine oxidase to 5-methoxyindoleacetaldehyde, which is further enzymatically metabolized to either 5-MIAA or 5-MTOL by aldehyde dehydrogenase and alcohol dehydrogenase, respectively (Grace et al., 1991; Rogawski et al., 1979; Slominski et al., 2005a). Recent studies performed on liver have indicated, however, that both mitochondrial and microsomal cytochrome P450s metabolize melatonin predominantly by 6-hydroxylation, with $O$-demethylation representing a minor metabolic pathway (Semak et al., 2008).

In the kynuric pathway, cleavage of the pyrrole ring of melatonin by indoleamine 2,3dioxygenase yields AFMK, which is further metabolized by arylamine formamidase to form N1-acetyl-5-methoxykynuramine (AMK) (Hardeland et al., 1993; Hirata et al., 1974). The kynurenic acid degradation pathway can also be executed by other enzymes, including peroxidase, and myeloperoxidase (reviewed in Slominski et al. (2008)). The free radical species have also been shown to be involved in a non-enzymatic kynurenic pathway (Tan et 
al., 2000, 2007). Additional route of melatonin degradation in mitochondria to AFMK by cytochrome $C$ was also described (Semak et al., 2005).

Melatonin is widely distributed in plants, unicellular organisms, algae, bacteria, invertebrates, and vertebrates (Hardeland and Poeggeler, 2003; Iriti et al., 2010; Stehle et al., 2011). Its uncommonly wide distribution allows it to carry out its pleiotropic functions (Celinski et al., 2011; Gomez-Moreno et al., 2010; Jung-Hynes et al., 2010; Paradies et al., 2010; Reiter, 1991a; Reiter et al., 2010; Slominski et al., 2008; Tan et al., 2007). In vertebrates, the roles of melatonin are numerous and include: regulating circadian rhythm and acting as a neuromodulator, hormone, cytokine and biological response modifier (Man et al., 2011; Reiter, 1991b). It also affects brain, immune, gastrointestinal, cardiovascular, renal, bone and endocrine functions, and acts as an oncostatic and anti-aging molecule (Celinski et al., 2011; Leja-Szpak et al., 2010; Pandi-Perumal et al., 2008; Slominski et al., 2008; Yu et al., 1993). Many of melatonin's actions are mediated through the interaction with specific membranereceptors. Examples include anticonvulsant and vasoconstrictor activity through activation of MT1 receptors, and vasodilation via activation of MT2 receptors (Masana et al., 2002). Melatonin has also been found to have a protective effect against myocardial infarction, to limit weight gain, and to inhibit the effects of estrogen (Boutin et al., 2005; Tan et al., 2011, 1998; Tengattini et al., 2008).

Melatonin also acts through non-receptor mediated mechanisms, for example serving as a scavenger for reactive oxygen species and reactive nitrogen species (Gomez-Moreno et al., 2010). The reactive species melatonin scavenges include hydroxyl radical $\left(\mathrm{HO}^{-}\right)$, hydrogen peroxide $\left(\mathrm{H}_{2} \mathrm{O}_{2}\right)$, nitric oxide $\left(\mathrm{NO}^{-}\right)$, and various others (Galano et al., 2011; Tan et al., 2001, 1993). Melatonin reacts with agents to form products that are not recycled back to melatonin, making it a "suicidal antioxidant" (Tan et al., 2001). Melatonin, in addition to being a broad-spectrum antioxidant, can also activate cytoprotective enzymes (Rodriguez et al., 2004). At both physiological and pharmacological concentrations melatonin attenuates or counteracts oxidative stress, and regulates cellular metabolism (Korkmaz et al., 2009; Slominski et al., 2005a, 2008; Tan et al., 2007). Some of these protective effects of melatonin are shared by its metabolite, AFMK (Tan et al., 2007).

Melatonin is synthesized in the pineal gland (Reiter, 1991c). After entering circulation melatonin acts as endocrine factor and a chemical messenger of light and darkness (circadian and circannual pacemaker) (Reiter, 1993). Evidence has accumulated that it is also produced in the various extra-pineal organs including the brain, retina, retinal pigment epithelium, gastrointestinal tract, bone marrow, lymphocytes, and the skin (Bubenik, 2002; Pandi-Perumal et al., 2008; Slominski et al., 2008; Tan et al., 2003). In these organs melatonin may signal in autocrine or paracrine modes, including the possibility that it acts via intracellular receptors expressed by the same cells that produces the molecules (Slominski et al., 2008; Tan et al., 2003). Also, locally produced melatonin could protect the cell from free radical-mediated damage.

\section{Melatonin receptors}

As of 2011, there have been two membrane bound melatonin receptors identified and characterized, MT1 and MT2. MT1 was known as Mel1 ${ }_{\mathrm{a}}$, and MT2 as $\mathrm{Mel}_{1 \mathrm{~b}}$ (Dubocovich et al., 2010, 1998). Both of them belong to the family of G protein-coupled, seven transmembrane receptors (Dubocovich et al., 2003; Witt-Enderby et al., 2003). Activation of either $\mathrm{G}_{\mathrm{i}}$ or $\mathrm{G}_{\mathrm{q}}$, depending on the receptor type, mediates intracellular signaling by modifying the activities of adenylate cyclase, phospholipases $\mathrm{C}$ and $\mathrm{A}_{2}$, potassium and calcium channels, and guanylyl cyclase (Pandi-Perumal et al., 2008). The existence of a third membrane bound melatonin binding site (MT3 receptor) was theorized at one time 
(Dubocovich, 1995). However, this biological target of melatonin was found to actually be the cytosolic enzyme, quinone reductase 2 (Nosjean et al., 2000; Vincent et al., 2010). Below, we discuss the signaling mechanism by each of these receptors and describe the primary pharmacological tools used to define them.

\subsection{MT1 receptor}

The MT1 receptor (Mel1c) was first cloned in frogs nearly 20 years ago (Ebisawa et al., 1994). The same group was the first to clone the mammalian MT1 receptor from sheep and humans (Reppert et al., 1994). The MT1 receptor is 350 amino acids in length and coupled to $\mathrm{G}_{\mathrm{i}}$, specifically $\mathrm{G}_{\mathrm{i} \alpha 2,}, \mathrm{G}_{\mathrm{i} \alpha 33}$, and $\mathrm{G}_{\mathrm{q} / 11}$. MT1 receptors are expressed in the brain, cardiovascular system (including peripheral blood vessels, aorta and heart), immune system, testes, ovary, skin, liver, kidney, adrenal cortex, placenta, breast, retina, pancreas and spleen (Dubocovich and Markowska, 2005; Fischer et al., 2008b; Pandi-Perumal et al., 2008; Slominski et al., 2005a, 2008). In the brain, the receptor is predominantly found in the hypothalamus, cerebellum, hippocampus, substantia nigra and ventral tegmental area (Pandi-Perumal et al., 2008). Subsequent investigation, however, may well identify even a larger range of the MT1 receptor.

\subsection{MT2 receptor}

The MT2 receptor was cloned by Reppert and his co-workers (Reppert et al., 1995) from brain, retina and human pituitary gland. The gene contains two exons and one intron and the final translated protein product consists of 363 amino acids and shows $60 \%$ homology to the MT1 receptor (Reppert et al., 1996a). The MT2 receptor is also a G-protein related and couples to the activation of $\mathrm{G}_{\mathrm{i}}$. MT2 has been found in the immune system, brain (hypothalamus, Suprachiasmatic Nucleus (SCN)), retina, pituitary, blood vessels, testes, kidney, gastrointestinal tract, mammary glands, adipose tissue, and the skin (Dubocovich et al., 2005; Reppert et al., 1995; Roca et al., 1996; Slominski et al., 2005a).

An orphan receptor called the melatonin related receptor (MRR) or GPR50 has 45\% amino acid homology to melatonin receptors (Dufourny et al., 2008). Despite this homology, melatonin does not bind to GPR50 and the identity of its real ligand is unclear (Reppert et al., 1996b). However, GPR50 may heterodimerize with the MT1 receptor and inhibit its activity (Levoye et al., 2006a,b).

\subsection{Quinone reductase II (NQO2; “MT3” receptor)}

Although the "MT3" receptor has not yet been found in humans, it is expressed in the hamster (Nosjean et al., 2001). The highest levels were found in the liver and the kidneys with moderate amounts in the heart, adipose tissue, and the brain (Nosjean et al., 2001). It is also expressed in the retina of the rabbit (Pintor et al., 2001). The properties of the "MT3" receptor include: it has a low affinity or 2-[ $\left.{ }^{125} \mathrm{I}\right]$ iodomelatonin, unlike MT1 and MT2 (Reppert et al., 1996b); it is not coupled to G proteins; it has a nanomolar affinity for melatonin and is not sensitive to $\mathrm{Na}^{+}, \mathrm{Mg}^{+2}, \mathrm{Ca}^{+2}$ (Dubocovich, 1995). Nosjean and his coworkers reported that "MT3" is equivalent to NQO2 (Nosjean et al., 2000). The three modulators for the "MT3" receptor, ranked from the lowest to highest affinity, are melatonin, resveratrol, and compound S29434 (Ferry et al., 2010).

\subsection{Nuclear receptors}

There are over 200 genes activated by nuclear receptors (Jetten, 2009); of these, melatonin may mediate its actions through the ROR/RZR (retinoid orphan receptors/retinoid Z receptors) group (Smirnov, 2001). The subfamilies that, according to some authors, bind melatonin include: RZR $\alpha$, ROR $\alpha$, ROR $\alpha 2$, and RZR $\beta$ (Becker-Andre et al., 1994; Carrillo- 
Vico et al., 2005). The structure of the nuclear receptors consist of an N-terminal domain, a DNA binding domain that contains a zinc double finger, a hinge region, and a ligandbinding domain included in the C-terminal (Jetten, 2009; Smirnov, 2001). The nuclear receptor groups are distributed according to their subtype, with RZR $\beta$ being found in neuronal tissues and RZR $\alpha$ in adipose tissue, the skin, testes, cartilage, and liver (Smirnov, 2001).

The question of whether melatonin interacts directly with these nuclear receptors has been a source of controversy. Becker-Andre and his co-workers had theorized that melatonin interacts with the nuclear receptors of the retinoic acid subfamily of orphan receptors (Becker-Andre et al., 1994; Carlberg et al., 1994). Thus, they summarized that melatonin acts as a ligand to the previously identified orphan receptor RZR $\beta$. These workers discovered this by cloning a cDNA of the RZR $\beta$. They then transfected drosophila SL-3 cells and HELA cells and measured binding of 2-[ ${ }^{125}$ I]Iodomelatonin to the nuclear receptor (Becker-Andre et al., 1994). Concurrently, Carlberg and his co-workers found that melatonin might interact with nuclear receptors of the retinoic acid subfamily of orphan receptors (ROR $\alpha /$ RZR) (Carlberg et al., 1994). A year later, Wiesenberg and co-workers used a similar technique, and confirmed that melatonin can also bind to RZR $\alpha$ and ROR $\alpha 1$ (Wiesenberg et al., 1995). However, some investigators question the ability of melatonin to bind to the nuclear receptor ROR $\alpha$ and to directly activate it (Dai et al., 2001). Importantly, the crystal structure of ROR $\alpha$ was obtained by Kallen and his co-workers and cholesterol sulfate was defined as the natural ligand for it (Kallen et al., 2004). Other compounds were also listed as potential ligands for ROR $\alpha$ nuclear receptor including cholesterol derivatives, however, melatonin was not cited among them (Bitsch et al., 2003).

Some investigators propose that melatonin indirectly regulates nuclear receptors via the MT1 membrane receptor that are known to be activated by melatonin (Dai et al., 2001; Ram et al., 2002). Ram and his co-workers tested this idea by measuring a ROR $\alpha$-luciferase reporter activity assay. They found that melatonin and $\mathrm{N}$-acetyl-4-aminomethyl-6methoxy-9-methyl-1,2,3,4-tetrahydrocarbazole (AMMTC) suppresses ROR $\alpha$ transcriptional activity, while CBPT (MT1 antagonist) reverses the effects of melatonin and AMMTC (Ram et al., 2002). Nevertheless investigators in the field of nuclear receptors question the hypothesis that melatonin is a native ligand for ROR (Jetten, 2009).

\subsection{Signaling by MT1 and MT2 receptors}

Morgan and his co-workers reported that the membrane bound melatonin receptors are coupled to the $G$ protein, $G_{i}$, in ovine pars tuberalis (Morgan et al., 1989). However, Abe and his co-workers were the first to show that melatonin inhibits the action of melanocyte stimulating hormone (MSH) and prevents the formation of cAMP (Abe et al., 1969). Both MT1 and MT2 receptors are found to be a part of the G protein-coupled receptor superfamily (Jockers et al., 2008). The G protein coupled receptors include $7 \alpha$ helical transmembrane domains and activate $G$ protein signaling pathways (Hall et al., 1999). Navajas and his collegues claimed that melatonin interacts with a binding pocket formed by helices V, VI, and VII of the receptor (Navajas et al., 1996). The MT1 receptor is coupled to the $\mathrm{G}$ protein subunits $\mathrm{G}_{\mathrm{i} 2}, \mathrm{G}_{\mathrm{i} 3}$, and $\mathrm{G}_{\mathrm{q} / 11}$ (Brydon et al., 1999).The $\mathrm{G}_{\mathrm{i}}$ coupled MT1 receptor lowers cAMP levels (Capsoni et al., 1994). $G_{i}$ exerts this action through the inhibition of adenylyl cyclase activity directly via $G_{i}$, but also via signaling by the $\beta \gamma$ subunit, which inhibits certain adenylyl cyclase isoforms and activates PLC $\beta$ and PLC $\varepsilon$ (Hildebrandt, 1997; Witt-Enderby et al., 2003). The MT1 receptor can also be coupled via $\mathrm{G}_{\mathrm{i}}$ to the Kir3 potassium channel (Nelson et al., 1996).

In some cells, MT1 receptors couple to $\mathrm{G}_{\mathrm{q} / 11}$ and the activation of phospholipase- $\mathrm{C}$, which in turn can increase calcium levels and activate signaling by calmodulin $(\mathrm{CaM}), \mathrm{CaM}$ 
kinases and calreticulin (Witt-Enderby et al., 2003). Membrane melatonin receptors also promote the activity of c-Jun-N-terminal kinase (JNK), but the precise signaling pathway for this action has not been clearly delineated (Chan et al., 2002). A schematic diagram of melatonin receptor signaling is shown in Fig. 2.

Interestingly, both MT1 and MT2 can form homo and heterodimers (Ayoub et al., 2002). Dimerization has been demonstrated via bioluminescence resonance energy transfer (BRET) (Ayoub et al., 2002). The same group observed that the MT1 homodimers occur at almost the same rate as the MT1-MT2 heterodimers, while the MT2 homodimers occur about 3-4 times less abundantly than the heterodimers (Ayoub et al., 2004). It is unclear what, if any, pharmacological properties or physiological effects of melatonin are dependent upon formation of these different receptor dimeric species.

\section{Melatonin receptors in the cardiovascular system}

\subsection{Vasculature}

Viswanathan et al. discovered melatonin receptors in vascular tissue though the use of 2$\left[{ }^{125}\right.$ I]iodomelatonin binding (Viswanathan et al., 1990). According to their calculations, the dissociation constant in the anterior cerebral artery was $3.4 \times 10^{-11} \mathrm{M}$, while it was $1.05 \times$ $10^{-10} \mathrm{M}$ in the caudal artery (Viswanathan et al., 1990). Melatonin has been found to be a vasorelaxant in the mesenteric artery and aorta (Girouard et al., 2001). In contrast, in the caudal artery, melatonin has also been found to be a vasoconstrictor (Krause et al., 1995; Ting et al., 1997). Interestingly, in a study performed by Doolen and co-workers, the vascular response of the caudal artery was shown to be dependent on the concentration of melatonin (Doolen et al., 1998). At concentrations of $10^{-10}-10^{-7} \mathrm{M}$, it was found to be a vasoconstrictor; however, at concentrations $10^{-7}-10^{-5} \mathrm{M}$, melatonin was found to reduce vasoconstriction (Doolen et al., 1998). After the addition of the MT2 antagonist 4P-ADOT, vasoconstriction with higher concentrations of melatonin was restored, showing that MT2 receptors could mediate vasoconstriction (Doolen et al., 1998). Masana and co-workers further explored the role of MT1 versus MT2 receptors in vascular activity. They documented that MT1 mediates vascular constriction, while MT2 mediates vasodilation (Masana et al., 2002).

\subsection{Melatonin as an antihypertensive molecule}

One potential pharmacological use of melatonin is in lowering hypertension.

When 23-week old rats were treated with $6 \mathrm{mg}$ melatonin daily for 5 days, they had a mean blood pressure $180 \mathrm{~mm} \mathrm{Hg}$ versus the $195 \mathrm{~mm} \mathrm{Hg}$ for the vehicle treated ones (Kawashima et al., 1987). Pinealectomy had previously been reported to have a slight hypertensive response: thus, blood pressure of pinealectomized rats was found to be $20 \mathrm{~mm} \mathrm{Hg} \mathrm{higher} \mathrm{on}$ average than sham operated rats (Holmes and Sugden, 1976; Zanoboni and ZanoboniMuciaccia, 1967). In an attempt to resolve this discrepancy, Lusardi and his colleagues performed a double blind study where human subjects were given $5 \mathrm{mg}$ of melatonin per day for 4 weeks (Lusardi et al., 1997). In this study, melatonin was found to reduce the blood pressure in humans by about $6 \mathrm{~mm} \mathrm{Hg}$ (Lusardi et al., 1997). Unexpectedly, when patients taking nifedepine (a calcium channel blocker and antihypertensive) were also given melatonin, the indoleamine actually caused the blood pressure of the nifedipine users to increase by $6 \mathrm{~mm} \mathrm{Hg}$ (Lusardi et al., 2000). The authors speculated that the melatonin might interact with calcium-calmodulin signaling (Lusardi et al., 2000). A number of authors have found that melatonin has been found to reduce the systolic blood pressure in humans (Gomez-Moreno et al., 2010; Paulis et al., 2010). 


\section{Melatonin receptors in the immune system}

The first study that demonstrated a connection between the immune system and the pineal gland was performed almost four decades ago, where pinealectomy caused a depression in the immune system (Csaba and Barath, 1975). These investigators also showed that the thymic cells had stopped proliferating following surgical removal of the pineal gland. Even earlier studies had been published the results of which hinted at melatonin's role in the immune system. In 1926, Bergman and co-workers gave the cats pineal gland extracts, and this resulted in the cats having a stronger immune system in so far as it could be measured (Carrillo-Vico et al., 2005). Another earlier study has shown that pinealectomy causes the thymus gland to shrink from 130 to $70 \mathrm{mg}$ in mice (Vaughan and Reiter, 1971). A likely correlation between pinealectomy and immune system depression was also confirmed by Beskonakli and co-workers, where removal of the pineal gland resulted in a reduction in the number of lymphocytes, erythrocytes, and leukocytes (Beskonakli et al., 2001).

The first study that showed a direct relationship between the immune system and melatonin was published by Maestroni and co-workers in 1986 (Maestroni et al., 1986). These investigators reported that the immune system function was inhibited by propanolol and $p$ chlorophenylalanine; however, when melatonin was administered, the immune system was restored to essentially normal levels (Maestroni et al., 1986). The potential role of opioid receptor antagonists (naltrexone and ICI 174864) in the regulation of melatonin's immunostimulatory effect. The results demonstrated that naltrexone decreases the amount of splenocyte activity by half, while ICI 174864 had no effect on melatonin's action (Maestroni et al., 1988). Thus melatonin modulates immune cell activity via $\mu$ - and k-opioid, but not $\partial$ opioid receptors. For additional information on the complex actions of melatonin on immune functions, the reader should consult following reviews (Carrillo-Vico et al., 2005; Kim et al., 2009).

\subsection{Melatonin receptor expression in immune cells}

The first major study to identify membrane melatonin receptors in the immune system was published by Lopez-Gonzalez and co-workers; in their report, they uncovered melatonin recepotors in lymphocytes (Lopez-Gonzalez et al., 1992). The MT1 receptor expressed in the thymus and the spleen, as well as in CD4, CD8, and B cells, while MT2 receptors were not detected in any of these cells (Pozo et al., 1997). The MT1 receptor is also expressed in U937 cells (Guerrero et al., 2000). Carillo-Vico and co-workers reported the presence of the MT2 receptor in the thymus, as well as confirming that the MT1 receptor is expressed in the thymus, spleen, and lymphocytes (Carrillo-Vico et al., 2003). In addition, MT2 receptor inhibits leukocyte rolling, while "MT3" receptor reportedly regulate the adhesion of leukocytes to the vascular endothelium (Lotufo et al., 2001).

\subsection{Nuclear receptors in the immune system}

Melatonin nuclear receptors reportedly influence the immune system physiology; these receptors were first proposed to be in the immune system by Menendez-Pelaez et al. (1993). Steinhilber and co-workers performed the first investigation that directly established a correlation between the nuclear melatonin receptors and the immune system, where the action of melatonin was in inhibiting 5-lipoxygenase syntheses in B lymphocytes (Steinhilber et al., 1995). The importance of nuclear receptors was also verified by GarciaMaurino's group Garcia-Maurino et al., 1997, who found that IL-2, IL-6, and INF- $\gamma$ synthesis in the CD4 cells was mediated at the level of the nucleus. They also found that nuclear receptors mediate the production of IL-2 and IL-6 production in both lymphocytic (Jurkat) cells and human peripheral mononuclear cells (Garcia-Maurino et al., 2000). Melatonin was found to activate the cells to produce both IL-2 and IL-6. That IL-2 
production is mediated by a nuclear melatonin receptor in U937 cells was claimed by Guerrero et al. (2000). However, these investigators used IFN- $\gamma$, which not only inhibits the MT1 receptor but also stimulates nuclear receptors.

A number of studies have examined to define the distribution of nuclear melatonin receptors. For example, the ROR $\alpha$ was found in both the thymus and spleen (Carrillo-Vico et al., 2003). In addition, nuclear receptors have been found in lymphocytes (Jurkat cells), human peripheral mononuclear cells (PBMCs), U937 cells, CD4 and CD8 cells (GarciaMaurino et al., 2000; Guerrero et al., 2000).

\subsection{Melatonin receptors, immune system, and seasonal differences}

In 1973, Vriend and Lauber measured the weight of spleens from deer mice after exposure to different light intensities. They found that spleen weights averaged $1.5 \mathrm{mg}$ after exposure to $3.6 \times 10^{11}$ photons, compared to $2.0 \mathrm{mg}$ when exposed to photons at $5.6 \times 10^{11}$ photons (Vriend and Lauber, 1973). They suspected that endogenously produced melatonin might have influenced the outcome of the study, although the melatonin levels were not actually measured. There is a reported direct correlation between melatonin levels at its peak during darkness, and the maximal immune cell proliferation (Carrillo-Vico et al., 2005). This was confirmed when mice treated with the MT1 and MT2 antagonist luzindole at different times of the light cycle; they observed that despite the time the luzindole was given, it blocked splenocyte proliferation (Drazen et al., 2001).

Nelson and Demas noted that melatonin and glucocorticoids mutually oppose one another, depending on the concentration (Nelson and Demas, 1997). Unlike melatonin, glucocorticoids have been found to inhibit splenocyte proliferation (Nelson and Demas, 1997). Since melatonin levels peak during the night and glucocorticoid levels peak during the day, they postulated that the reason for the variation in splenocyte proliferation through the day was due to this melatonin-glucocorticoid opposition. They also reported that during longer days, mice had reduced immunoglobulin $\mathrm{G}(\mathrm{IgG})$ expression and lower levels of melatonin release (Demas and Nelson, 1996). Another study by Mahmoud and colleagues observed that rats that were exposed to constant dark for 4 weeks showed a 3-fold increase in their thymus weight (Mahmoud et al., 1994).

\section{Melatonin receptors in the endocrine system}

Melatonin appears to play key roles in the regulation of the endocrine system. These roles include regulation of GnRH (gonadotrophin releasing hormone) release, stimulation of oxytocin secretion, promotion of progesterone synthesis release, regulation of cortisol production, and promotion of androgen production (Balik et al., 2004; Schaeffer and Sirotkin, 1995; Tamura et al., 2009, 2008). Species differences exist in melatonin receptor expression and action on the endocrine system.

\subsection{Melatonin receptor localization}

Melatonin receptors have been found in various tissues throughout the endocrine system. MT1 and MT2 receptors have been found to be expressed in the pituitary gland, although MT2 are less prevalent (Balik et al., 2004). Immunoblot analysis of murine line GnRH secreting neurons was used to demonstrate expression of MT1 and MT2 receptors, as well as the nuclear receptors ROR $\alpha$ and RZR $\beta$ (Roy et al., 2001). Soras et al. in 2003 MT1 and MT2 are present in the rat ovaries as demonstrated by RT-PCR and 2-[ $\left.{ }^{125} \mathrm{I}\right]$ iodomelatonin binding (Soares et al., 2003). Niles and co-workers in 1999 used RT-PCR to detect MT1 and MT2 receptor expression in human granulosa cells (Niles et al., 1999), the findings confirmed by others Woo et al. (2001). MT1 receptor expression has been detected in the adrenal glands of capuchin monkeys (Torres-Farfan et al., 2003). This was confirmed in rat 
adrenal gland tissue, however, MT2 receptors were not expressed (Richter et al., 2008).

Furthermore, MT1 receptors are expressed in sperm cells (Casao et al., 2010).

\subsection{GnRH and other sex hormones regulation}

Melatonin has been found to decrease GnRH, LH and FSH levels (Lang et al., 1983).

Vanecek and Vollrath found that melatonin's inhibition of cAMP and cGMP production causes the inhibition of GnRH release (Vanecek and Vollrath, 1990). They also found that melatonin's inhibitory effect is especially pronounced in rats younger than 14 days of age (Vanecek and Vollrath, 1990). There have been other mechanisms proposed that explain melatonin's inhibitory effect on GnRH. Roy and colleagues used Northern blot to find that melatonin can also affect GnRH expression at the transcriptional level (Roy et al., 2001). This group also found that the melatonin receptor inhibitor, luzindole, attenuates melatonin's inhibitory effect on GnRH release (Roy et al., 2001). Another group, led by Woo and coworkers has found that melatonin's action on GnRH works via regulating mitogenic responses via MAPK signaling (Woo et al., 2001). Roy and colleagues gave further evidence of this phenomenon by showing that kinase inhibitors prevent melatonin from blocking GnRH release (Roy and Belsham, 2002). Balik and colleagues also wrote that melatonin blocks GnRH release by preventing oscillatory calcium release (Balik et al., 2004). However, these investigators also mention that melatonin does not by itself prevent calcium release, rather it depends on the melatonin receptor for this action (Balik et al., 2004).

The discovery that melatonin promotes progesterone release was made by Webley and Luck over 25 years ago (Webley and Luck, 1986). They found that melatonin exerts this effect at high concentrations $(200 \mathrm{pg} / \mathrm{ml})$ and for a fairly long duration $(8 \mathrm{~h})$. Woo and co-workers have found that melatonin has no effect on progesterone secretion from human granulosaluteal cells (Woo et al., 2001). On the contrary other authors claimed that melatonin stimultes progesterone production when cells are given hGC and that LH receptors were upregulated and $\mathrm{GnRH}$ receptors upregulated in ovaries.

\subsection{Regulation of cortisol production}

Although it has been more than 20 years since it has been shown, that melatonin can inhibit serum cortisol levels (Aoyama et al., 1986), only recently the mechanism in which melatonin directly regulates cortisol production was uncovered. MT1 receptors have been found to directly inhibit cortisol production in the adrenal glands of capuchin monkey (Torres-Farfan et al., 2003). These investigators used luzindole to antagonize melatonin receptors, as well as RT-PCR to show that only MT1 receptors are expressed in the adrenal gland. They later reported that melatonin also prevents the adrenal gland from responding to ACTH (Richter et al., 2008). This group indicated that the MT1 receptors seem to also act on the 3 $\beta$-HSD enzyme, which is needed for cortisol production (Torres-Farfan et al., 2004).

\subsection{Melatonin and diabetes}

Scientists have been investigating the role of the pineal gland in glucose metabolism for more than 70 years (Peschke, 2008). Rats with the pineal gland removed have been found to have an increase in their glucose levels (Gorray and Quay, 1978). Pinealectomy also reduces the adipose tissue's response to insulin (Lima et al., 1998). Boden and colleagues noticed that insulin secretion increases during the day, while melatonin secretion decreases (Boden et al., 1996). Melatonin secretion has been found to decrease with age, and giving it to these older rats has been found to restore insulin, leptin, and visceral fat levels to the level of younger rats (Rasmussen et al., 1999). In 2009, there were three single nucleotide polymorphisms (SNPs) identified near the MT1 receptor gene (specifically, rs2166706, 
rs1387153, and rs10830963) that are correlated with a higher instance of type 2 diabetes (Chambers et al., 2009).

\subsection{Localization of the melatonin receptors in the endocrine pancreas}

Both MT1 and the MT2 receptors have been found to be present in the pancreas (Peschke, 2008). In 2002, Peschke found that MT1 receptors are present in the pancreatic islets, while MT2 receptors are also present but in smaller quantities (Peschke, 2008). Muhlbauer and Peschke also discovered that both MT1 and MT2 receptors are present in the islets of Langerhans (Muhlbauer and Peschke, 2007). Ramracheya and co-workers confirmed the presence of MT1 and MT2 receptors in the islet of Langerhans, and further described that MT1 receptors are present in $\alpha$ cells, but not in $\beta$ cells (Ramracheya et al., 2008). Peschke also reported that the melatonin nuclear receptors ROR $\alpha, \mathrm{RZRB}$, and ROR $\gamma$ can be detected in the pancreatic tissues (Peschke, 2008).

The melatonin receptors are coupled to a $\mathrm{G}_{\mathrm{i}}$ protein that inhibits adenylyl cyclase and cAMP to mediate its signal transduction (Peschke, 2008). This was demonstrated when luzindole was added to the pancreatic islets, resulting in the inhibition of melatonin's signaling. Peschke and colleagues in 2000 found that the G protein-coupled receptor can also act through the phospholipase C/IP3 pathway (Peschke et al., 2000). Picinato and colleagues has shown that melatonin reduces cAMP production in the pancreas and INS-1 cells (Picinato et al., 2008). They also found that melatonin induces production of insulin growth factor (IGF) and promotes insulin receptor tyrosine phosphorylation (Picinato et al., 2008). This in turn activates PI3K/AKT and MEK/ERK pathways (Picinato et al., 2008). In addition, an increase in calcium levels by melatonin can stimulate glucagon production (Ramracheya et al., 2008).

\section{Melatonin receptors in the reproductive and gestational tissues}

\subsection{Uterus}

6.1.1. Myometrium-An important feature of the uterus is the well-defined 24-h rhythm of contractility and electrical and endocrine activities in rodents, primates, and humans (Lindström et al., 1984; Seron-Ferre et al., 1993). A classic example of such circadian activity is the 24-h rhythm of spontaneous birth in humans (Myers and Nathanielsz, 1993; Nathanielsz, 1994; Olcese, 2012; Panduro-Baron et al., 1994), with maximal birth rate values during the night, at a time coinciding with maximal pineal melatonin secretion (Arendt, 1996). The fact that the light-dark cycle can regulate the daily timing of birth and uterine contractility has been shown for baboons, rhesus macaques (Ducsay and Yellon, 1991; Figueroa et al., 1990) and rats (Pang et al., 1985). Moreover, the increase of the blood flow to the placenta during the night seems to play an important role in the parturition (Harbert et al., 1979).

Melatonin plays an important role in the uterine contractility in rodents; however, the expression of circadian activity differs from the pattern in humans with the peak of activity at night compared to the day time. There were no effect of melatonin, for example on the uterine contractility in sheep (Sadowsky et al., 1991). To the best of knowledge the uterine melatonin receptors in sheep have not been described yet. MT1 receptor has been described in the rat myometrium (Zhao et al., 2002) where it decreased uterine contractility (spontaneous and oxytocin-induced) (Ayar et al., 2001).

Many studies showed a clear $24 \mathrm{~h}$ circadian patterns in myometrial activity in the pregnant non-human primate (Figueroa et al., 1990; Honnebier et al., 1991; Honnebier and Nathanielsz, 1994). Contractures switch to contractions at night time and the activity reverses back to contractures the following day. This switch occurs for several nights before 
delivery finally occurs (Morgan et al., 1992). In the human uterus the functional MT1 and MT2 receptors have been detected (Schlabritz-Loutsevitch et al., 2003). The expression of these receptors differs in pregnant and non-pregnant uterus.

6.1.2. Endometrium-2-[ $\left.{ }^{125} \mathrm{I}\right]$ iodomelatonin binding and MT1 transcript was described in rat endometrium during estrous cycle (Zhao et al., 2002). The expression of these receptors is up-regulated by the melatonin treatment and is associated with the downregulation of the ER-beta and PRB (Chuffa et al., 2011). Influence of the melatonin on the incidence of endometrial cancer has been suggested (Sandyk et al., 1992) and the presence of the functional MT2 receptor was detected in the estrogen positive cell line derived from patient with endometrial carcinoma (Kobayashi et al., 2003).

6.1.3. Placenta-Human amniotic epithelial cells expressed MT1, but not MT2 receptors (Kaneko et al., 2011). MT1 and MT2 mRNA expression was demonstrated in the first trimester placenta (Iwasaki et al., 2005). In the placenta at term immunohistochemistry showed the presence of melatonin receptors (MT1, MT2, and ROR $\alpha$ in both villous cytotrophoblast and syncytiotrophoblast (STB) as well as in endothelial cells of fetal capillaries and in the villous mesenchymal core (Lanoix et al., 2008). All three receptors were detected using RT-PCR, Western blotting and confocal microscopy in the human term placental tissues and in choriocarcinoma cell lines JEG-3 and BeWo (Lanoix et al., 2006). Interestingly, the MT2 receptors have been found on the nuclear surface in addition to the usual location on the membrane surface. It was reported that human term villous trophoblast expresses melatonin synthesizing enzymes and produces 255 times more melatonin than the pineal gland (Lanoix et al., 2008). Anti-apoptotic action of melatonin on the trophoblast through the MT1 and MT2 dependent pathways was also demonstrated (Lanoix et al., 2012). Furthermore, mRNA transcripts of the melatonin-synthesizing enzymes and both MT1 and MT2 melatonin receptors were demonstrated in the first-tri- mester human placenta (Iwasaki et al., 2005). MT1 was also detected in the rat placenta, and melatonin agonist decreased the expression of placenta lactogen-II (PL-II) mRNA in cultured late-pregnancy rat placental tissues (Lee et al., 1999, 2003).

Most recently an in-depth review on differential effects of melatonin on the human trophoblast has been published (Lanoix et al., 2012).

\subsection{Mammary gland}

6.2.1. Mammary gland development-The binding sites for the $2-\left[{ }^{125} \mathrm{I}\right]-$ melatonin were found in the membrane and nuclei of mice mammary glands (Coto-Montes et al., 2003; Recio et al., 1994). The binding depends on the developmental (puberty, pregnancy), hormonal (estrus) and diurnal rhythm. The expression of MT1 receptor gene in the breast tissues is decreased in the rat model of aging (Hill et al., 2010). This decline has been associated with the increased incidence of ovarian cancer.

6.2.2. Breast cancer-Risk of the development of the breast cancer increased in the areas located north to the equator (Borisenkov and Anisimov, 2011). The role of the light pollution and the attendant effect on pineal gland in the breast cancer development has been suggested decades ago (Anisimov, 2003; Anisimov et al., 2005; Cohen et al., 1978; Cos et al., 2006; Cos and Sánchez-Barceló, 2000; Danforth et al., 1983). Melatonin administration has been shown to decrease, but in some cases to increase or having no effect on the development of the mammary gland tumors in mice and rats (Anisimov, 2003). In the breast tissue melatonin receptors modulate estrogen receptor binding (Danforth et al., 1983). MT1 receptor is expressed in MCF-7 and MDA-MB-231 (human breast cancer cell lines) and in the breast cancer tissues (Ram et al., 2002; Rogelsperger et al., 2011; Treeck et al., 2006). In 
MCF-7 cells melatonin reversibly inhibited cell proliferation and cell invasion (Mao et al., 2010). As confirmed by immunohistochemistry and immunofluorescent/confocal microscopy, MT1 receptor signal is localized in calveoli (Lai et al., 2008, 2009). There is a crosstalk between MT1 receptor and estrogen receptors pathways in the breast cancer (Cos et al., 2006). The MT1 expression is down regulated by exogenous estradiol and melatonin in MCF-7 cells. Moreover the MT1 receptors expression is up regulated in the estrogens receptors negative cells (MDA-MB-231) and down regulated in the estrogens receptors positive cells (MCF-7) (Girgert et al., 2009). Recently identified microRNA such as Piwi associated RNA is regulating MT1 gene expression as well (Esposito et al., 2011).

\subsection{Ovarian tissue}

To the best of our knowledge the melatonin in ovaries has been described extensively only in human, but not in non-human primates. Melatonin plays as important role in the regulation of the ovarian function and it has been detected in the human follicular fluid (FF) (Brzezinski et al., 1987; Ronnberg et al., 1990). The FF melatonin had functional effect on the progesterone production of human granulosa cells (GCs) (Brzezinski et al., 1992; Webley and Luck, 1986; Webley et al., 1988). The $\left[{ }^{3} \mathrm{H}\right]$ melatonin binding sites in cytoplasmic fractions of human ovaries were described by Cohen et al. decade earlier, in 1978 (Cohen et al., 1978). Subsequently melatonin-binding sites were detected in GCs using $2-\left[{ }^{125}\right.$ I]iodomelatonin (Yie et al., 1995), MT1 and MT2 gene expression was documented in human GCs with the prevalence of MT1 receptor (Niles et al., 1999). In human GCs melatonin increased LH receptor mRNA levels via the mitogen-activated protein kinase pathway and activation of Elk-1 (Woo et al., 2001) and stimulates oxytocin and insulin-like growth factor-I release (Schaeffer and Sirotkin, 1995, 1997). Moreover, treatment with melatonin protects luteinizing GCs from ROS (Taketani et al., 2011) and improves oocyte quality in IVF cycles (Tamura et al., 2009). This finding indicates that melatonin might activate both: different receptors and signal molecules. Interestingly, the proteomic data from human cumulus cells and mural GCs from the antral follicle did not include melatonin receptor (Huang and Wells, 2010). The importance of melatonin receptors is also suggested by an association of the single nucleotide polymorphism (SNP) with the pathology of the ovarian function. In the population of Chinese women SNP in the MT2 gene, rs10830963, is the predisposing factor to the poly-cystic ovarian syndrome (Li et al., 2011).

MT1 receptors have been described in the human SK-OV-3 and OVCAR-3 ovarian carcinoma cell lines, where their expression was up-regulated by melatonin treatment (Treeck et al., 2006).

\section{Melatonin receptors in the skin}

In 1958 Lerner discovered that melatonin can cause lightening of the skin of frogs (Lerner et al., 1959). We now appreciate many functions of melatonin in the skin, including scavenging of free radicals, protection of fibroblasts and keratinocytes from UV radiation, promotion of the anagen phase of the hair follicle, stimulation or inhibition of keratinocyte proliferation (depending on concentration), blockade of apoptosis, and prevention of carcinogenesis (Fischer et al., 2008a; Kobayashi et al., 2005; Slominski et al., 2008, 2005b,c). Melatonin also regulates melanin pigmentation (Slominski et al., 2005a, 2004b) and has a potential utility in melanoma treatment (Fischer et al., 2006; Slominski et al., 2005c). Several studies have given additional evidence of the importance of melatonin in the skin. Esrefoglu et al. pinealectomized rats and then tracked them for 6 months (Esrefoglu et al., 2005). Half of the rats were then given melatonin $(4 \mathrm{mg} / \mathrm{kg})$ during the last month of the study. Pinealectomized rats showed reduced skin thickness and atrophy of the epidermis, dermis, and the hair follicles (Esrefoglu et al., 2005). By comparison, the rats that were given melatonin showed reduced skin abnormalities. Furthermore, "MT3" receptor knockout 
mice exposed to carcinogens (benzopyrene and dimethyl-benzanthracene) displayed a higher incidence of developing skin cancer than wild type mice (Iskander et al., 2004).

\subsection{Localization of melatonin receptor expression in the skin}

MT1 and MT2 receptors have been found in the skin, as have the nuclear receptors ROR $\alpha 1$, ROR $\alpha 2$, and RZR, and "MT3" (Fischer et al., 2008a; Slominski et al., 2008). These findings confirm prior detection of melatonin binding sites in the epidermis and hair follicles of mouse skin (Slominski et al., 1994) and in cultured melanoma cells (Slominski and Pruski, 1993). Expression of MT1 and MT2 measured by RT-PCR made it clear that receptor expression depends on the species and cellular compartments (Slominski et al., 2005c) as well as on environmental regulation, which induced alternative splicing (Slominski et al., 2005a). MT1 receptor expression has been detected by immunocytochemistry in skin stratum granulosum, stratum spinosum, upper and inner root sheath, eccrine sweat gland, and blood vessel endothelium. MT2 receptor expression has been detected in the inner root sheath, eccrine sweat gland, and blood vessel endothelium (Slominski et al., 2005c). MT2 receptors are not as highly expressed in the epidermal cells of human skin, but are expressed in the epidermis of C57BL/6 mice (Slominski et al., 2005c). Kobayashi and colleagues has found MT2 and ROR $\alpha$ receptor expression in hair follicles (Kobayashi et al., 2005). "MT3" receptor expression has been detected in keratinocytes, melanocytes, and fibroblasts (Slominski et al., 2005a). The nuclear receptors ROR $\alpha /$ RZR have been found in adult and neonatal normal and immortalized epidermal keratinocytes, normal epidermal melanocytes, dermal fibroblasts and melanomas (Slominski et al., 2005a,c). For most comprehensive reviews on melatonin and the skin we refer to (Fischer et al., 2008b; Slominski et al., 2005a, 2008a, 2005c).

\subsection{Hair growth}

An early study claimed that melatonin had an inhibitory effect on hair regrowth (Houssay et al., 1966). Recent evidence however suggests otherwise (Fischer et al., 2004; Ibraheem et al., 1994). Adding melatonin at various concentrations (50-300 $\mathrm{ng} / \mathrm{L})$ to hair follicles collected from goats promoted hair growth (Ibraheem et al., 1994). The fur growth in rodents may be mediated by melatonin binding sites/receptors expressed in hair follicles, since these were identified in the murine skin showing hair cycle dependent pattern of expression (Kobayashi et al., 2005; Slominski et al., 1994). Also melatonin has been found to promote the anagen phase of murine hair cycle and these actions seem to be mediated by the MT2 receptor, as this is the predominate receptor in the cells of question (Kobayashi et al., 2005; Slominski et al., 2004a). These findings prompted a randomized, double-blind study of hair growth in women suffering from androgenic alopecia. Subjects were given melatonin $(0.1 \%)$ topically each evening for 6 months. Melatonin caused increased hair growth in patients with androgenetic alopecia, but not in patients suffering from diffuse alopecia (Fischer et al., 2004). These effects were interpreted as induction of hair growth by prolongation of the anagen phase, in part via retardation of the transition to catagen and/or by promotion of the transition from telogen to anagen (Fischer et al., 2008a). These clinical studies provided evidence for a positive effect of melatonin in human hair growth, indicating that melatonin receptors are realistic target for hair growth regulation in humans (Fischer et al., 2008a). For more detailed review on melatonin and hair growth we refer to (Fischer et al., 2008a), while on melatonin and hair or skin pigmentation to (Slominski et al., 2004b, 2005b).

\subsection{Vitiligo}

There are two main theories about the causes of vitiligo, a skin condition where pigment is lost in patches of otherwise normal skin. One theory is that vitiligo is caused by the immune system attacking the melanocytes, while others feel that the abnormal function of a 
metabolic pathway affects the melanocyte (Dell'anna and Picardo, 2006). Lerner proposed in 1960 that excessive melatonin in the peripheral nerve lightens the skin, and that it can also decrease melanin formation (Lerner, 1960). This prompted a proposal that melatonin may have play a role in vitiligo. Specifically it was postulated that a deregulation of melanogenesis, which involves activation of melatonin receptor, causes the destruction of melanocytes due to accumulation of toxic intermediates of melanogenic pathway, and as consequence vitiligo (Slominski et al., 1989). The proposed mechanism is that the overactive melatonin receptor blocks the melanin synthesis pathway, causing a buildup of toxic intermediate products and autodestruction of melanocytes (Slominski et al., 1989). Since the central role of melatonin receptors in vitiligo was questioned by some authors (Schallreuter et al., 2008), the same authors explained further that the interference with melanogenesis could be due to a mutated or malfunctioning melatonin receptor rather than activation of normal receptor (Slominski et al., 2008). Furthermore, the excess of melatonin could in fact protect cells because of free radical scavenging activities of melatonin and its metabolites (Slominski et al., 2008). The definitive role of melatonin in vitiligo is obviously still subject to debate.

\section{Melatonin receptors in the gastrointestinal tract}

The first major report of melatonin activity in the GI tract was by Quastel and Rahamimoff, who reported that melatonin decreased spontaneous contraction of the intestine (Quastel and Rahamimoff, 1965). Immunohistochemistry was used to identify melatonin localization in the mucous membrane in the intestine (Bubenik et al., 1977). Melatonin was also detected in the colon of rats by using immunofluorescence microscopy (Holloway et al., 1980). Not only is melatonin found in the GI tract, but evidence favors the idea that it can be produced locally by the intestine. Both of the rate limiting enzymes for melatonin production,

AANAT and HIOMT, are expressed in the intestinal wall (Konturek et al., 2007a). Further, melatonin levels can be from 10 to 100 times greater in the intestine than in serum (Bubenik, 2008).

Melatonin plays various important roles in the GI tract. One role is to act as a physiological antagonist to serotonin (Bubenik, 2008). Although the mechanism is unknown, there are two theories for this action: melatonin blocks serotonin by acting through the CCK2 and 5HT3 receptors (Thor et al., 2007), or melatonin acts through the MT2 receptor to oppose serotonin's action (Bubenik, 2008). Melatonin secretion is also found to increase in the intestine during fasting (Bubenik, 2008). The role of this increase in melatonin secretion could be to decrease peristalsis, thus giving the body more time to absorb nutrients in food. Melatonin can also stimulate the secretion of mucosal bicarbonate through increasing the calcium release in the enterochromaffin cell (Sjoblom et al., 2003). This action seems to be mediated by the MT2 receptor, as both luzindole and the MT2 receptor antagonist $\mathrm{N}$ pentanoyl-2-benzyltryptamine (DH 97) inhibit melatonin's actions (Sjoblom et al., 2003). Melatonin has also been found to increase pancreatic secretion of amylase and cholecystokinin via activation of MT2 receptors (Jaworek et al., 2007). An important receptor-independent action of melatonin in the GI tract is its action as a free radical scavenger (Konturek et al., 2006). Importantly, preventive role of melatonin against ulcer formation or its healing is well established (Brzozowska et al., 2009; Celinski et al., 2011; Ganguly et al., 2010; Konturek et al., 2008, 2006).

\subsection{Localization of melatonin receptors in the GI tract}

Melatonin receptors have been found throughout the GI tract, with the fewest amount of the receptors in the mouth and intestine, and the highest amount in the colon and jejunum (Konturek et al., 2007a). Although both MT1 and MT2 receptors are expressed throughout the GI tract, it seems that the MT2 receptor predominates (Konturek et al., 2007b). The MT2 
receptors have also been detected in enterochromaffin cells in the intestine (Sjoblom et al., 2003). Although co called "MT3" receptor has not been found in humans to date, they have been detected in the intestine of hamsters. Paul et al. used two drugs to show the presence of "MT3" receptors: prazosin, which block both $\alpha 1$ adrenergic and "MT3" receptors, and MCNAT, a putative ligand for "MT3" receptors (Paul et al., 1999).

\section{Melatonin receptors in bone}

The membrane melatonin receptors have been detected in both osteoblasts and osteoclasts using the ligand 2-bromomelatonin (Suzuki et al., 2008). MT1 receptors have also been found in osteosarcoma cells and even in bone marrow stroma cells (Toma et al., 2007). MT1 receptors have also been detected in secretory ameloblasts, the cells of the stratum intermedium and stellate reticulum, external dental epithelial cells, odontoblasts, and dental sac cells (Kumasaka et al., 2010). Melatonin has therapeutic activity in bones, as it promotes osteoblastic differentiation and bone strengthening (Roth et al., 1999). Cardinali et al. reported that melatonin not only increases osteoblastic activity, but also inhibits osteoclasts and even promotes the osteoblastic protein osteoprotegrin (Cardinali et al., 2003; Koyama et al., 2002). Thus, melatonin could potentially be used as a therapy for osteoporosis.

\section{Melatonin receptors in kidneys}

Melatonin receptors are expressed in the duck kidney, as detected by Song et al. nearly 20 years ago (Song et al., 1992). Melatonin receptors are expressed predominately in the kidney membrane area and basolateral membranes (Song et al., 1997). Drew et al. also reported that MT1 and MT2 receptors are expressed in the human fetal kidney cortex (Drew et al., 1998). Melatonin has several applications related to the renal system. Quiroz et al. described that melatonin can protect the kidneys from inflammation that can cause renal damage (Quiroz et al., 2008). Melatonin can protect the kidneys from oxidative damage done by mercuric chloride and can even regulate glomular filtration (Drew et al., 1998; Nava et al., 2000).

\section{Conclusions}

Although melatonin was identified for more than 50 years ago, only more recently have scientists begun to discover its numerous actions in peripheral tissues. Table 1 summarizes the expression of the different melatonin receptors in peripheral tissues and the primary physiological effects in each. The many roles of melatonin include regulation of circadian rhythms, acting as a neurotransmitter or a hormone to regulate numerous organ systems, and as an antioxidant (Reiter et al., 2000; Tan et al., 1993). Some of these actions are mediated through its G protein coupled membrane receptors: MT1 and MT2, while others are believed to be receptor independent (Dubocovich and Markowska, 2005; Reiter et al., 2007).

Although "MT3" receptors have not yet been found in humans, they have been found to be expressed in the various tissues of both hamsters and rabbits (Nosjean et al., 2000; Pintor et al., 2001).

Melatonin can also act on the retionic acid family of nuclear receptors to mediate many of its actions (Smirnov, 2001). How exactly melatonin interacts with the nuclear receptors remains a controvertial topic. Carlberg and Wiesenberg found that melatonin can directly interact with the nuclear receptors (Carlberg et al., 1994), whereas Ram and collegueas believe that melatonin mediates its actions on the nuclear receptors through MT1 receptor activation (Ram et al., 2002). More investigation is needed to determine how melatonin regulates these nuclear receptors, since based on the crystal structure of ROR cholesterol sulfate but not melatonin was defined as its natural ligand (Kallen et al., 2004). 
Also under active investigation is whether a mutated melatonin receptor causes vitiligo. As technology progresses, molecular and genetic tools are being utilized to discover melatonin receptor expression and their physiological roles in physiology and disease. These receptors make attractive pharmacological targets for immunomodulation, regulation of endocrine functions, anti-cancer activity, circadian activity, cardiovascular activity, skin pigmentation, hair growth and aging. Thus, expanding our knowledge of the expression, regulation, signaling and function of melatonin receptors in peripheral cells and tissues may have an impact on the pharmacotherapy of a wide array of diseases.

\section{Acknowledgments}

The review is dedicated to Dr. Aaron B. Lerner who discovered and defined the structure of melatonin. The manuscript was in part supported by the Grant 1R01AR056666-01A2 from NIH/NIAMS to A.S. and HL079166 from NIH/NHLBI to R.S.O.

\section{References}

Abe K, Robison GA, Liddle GW, Butcher RW, Nicholson WE, Baird CE. Role of cyclic AMP in mediating the effects of MSH, norepinephrine, and melatonin on frog skin color. Endocrinology. 1969; 85:674-682. [PubMed: 4308478]

Anisimov VN. The role of pineal gland in breast cancer development. Crit Rev Oncol Hematol. 2003; 46:221-234. [PubMed: 12791421]

Anisimov VN, Ukraintseva SV, Yashin AI. Cancer in rodents: does it tell us about cancer in humans? Nat Rev Cancer. 2005; 5:807-819. [PubMed: 16195752]

Aoyama H, Mori W, Mori N. Anti-glucocorticoid effects of melatonin in young rats. Acta Pathol Jpn. 1986; 36:423-428. [PubMed: 3716796]

Arendt J. Melatonin. Clin Endocrinol (Oxf). 1988; 29:205-229. [PubMed: 3073883]

Arendt J. Melatonin. BMJ. 1996; 312:1242-1243. [PubMed: 8634605]

Ayar A, Kutlu S, Yilmaz B, Kelestimur H. Melatonin inhibits spontaneous and oxytocin-induced contractions of rat myometrium in vitro. Neuroendocrinol Lett. 2001; 22:199-207. [PubMed: 11449192]

Ayoub MA, Couturier C, Lucas-Meunier E, Angers S, Fossier P, Bouvier M, Jockers R. Monitoring of ligand-independent dimerization and ligand-induced conformational changes of melatonin receptors in living cells by bioluminescence resonance energy transfer. J Biol Chem. 2002; 277:2152221528. [PubMed: 11940583]

Ayoub MA, Levoye A, Delagrange P, Jockers R. Preferential formation of MT1/MT2 melatonin receptor heterodimers with distinct ligand interaction properties compared with MT2 homodimers. Mol Pharmacol. 2004; 66:312-321. [PubMed: 15266022]

Balik A, Kretschmannova K, Mazna P, Svobodova I, Zemkova H. Melatonin action in neonatal gonadotrophs. Physiol Res. 2004; 53 (Suppl 1):S153-S166. [PubMed: 15119946]

Becker-Andre M, Wiesenberg I, Schaeren-Wiemers N, Andre E, Missbach M, Saurat JH, Carlberg C. Pineal gland hormone melatonin binds and activates an orphan of the nuclear receptor superfamily. J Biol Chem. 1994; 269:28531-28534. [PubMed: 7961794]

Beskonakli E, Palaoglu S, Aksaray S, Alanoglu G, Turhan T, Taskin Y. Effect of pinealectomy on immune parameters in rats with Staphylococcus aureus infection. Neurosurg Rev. 2001; 24:26-30. [PubMed: 11339464]

Bitsch F, Aichholz R, Kallen J, Geisse S, Fournier B, Schlaeppi JM. Identification of natural ligands of retinoic acid receptor-related orphan receptor alpha ligand-binding domain expressed in Sf9 cells a mass spectrometry approach. Anal Biochem. 2003; 323:139-149. [PubMed: 14622968]

Boden G, Ruiz J, Urbain JL, Chen X. Evidence for a circadian rhythm of insulin secretion. Am J Physiol. 1996; 271:E246-E252. [PubMed: 8770017]

Borisenkov MF, Anisimov VN. Cancer risk in women: a possible connection with geographic and certain economic and social factors. Vopr Onkol. 2011; 57:343-354. [PubMed: 21882606] 
Boutin JA, Audinot V, Ferry G, Delagrange P. Molecular tools to study melatonin pathways and actions. Trends Pharmacol Sci. 2005; 26:412-419. [PubMed: 15992934]

Brydon L, Roka F, Petit L, de Coppet P, Tissot M, Barrett P, Morgan PJ, Nanoff C, Strosberg AD, Jockers R. Dual signaling of human Mel1a melatonin receptors via G(i2), G(i3), and G(q/11) proteins. Mol Endocrinol. 1999; 13:2025-2038. [PubMed: 10598579]

Brzezinski A, Seibel MM, Lynch HJ, Deng MH, Wurtman RJ. Melatonin in human preovulatory follicular fluid. J Clin Endocrinol Metab. 1987; 64:865-867. [PubMed: 3818907]

Brzezinski A, Fibich T, Cohen M, Schenker JG, Laufer N. Effects of melatonin on progesterone production by human granulosa lutein cells in culture. Fertil Steril. 1992; 58:526-529. [PubMed: 1521647]

Brzozowska I, Ptak-Belowska A, Pawlik M, Pajdo R, Drozdowicz D, Konturek SJ, Pawlik WW, Brzozowski T. Mucosal strengthening activity of central and peripheral melatonin in the mechanism of gastric defense. J Physiol Pharmacol. 2009; 60 (Suppl 7):47-56. [PubMed: 20388945]

Bubenik GA. Gastrointestinal melatonin: localization, function, and clinical relevance. Dig Dis Sci. 2002; 47:2336-2348. [PubMed: 12395907]

Bubenik GA. Thirty four years since the discovery of gastrointestinal melatonin. J Physiol Pharmacol. 2008; 59 (Suppl 2):33-51. [PubMed: 18812627]

Bubenik GA, Brown GM, Grota LJ. Immunohistological localization of melatonin in the rat digestive system. Experientia. 1977; 33:662-663. [PubMed: 324794]

Capsoni S, Viswanathan M, De Oliveira AM, Saavedra JM. Characterization of melatonin receptors and signal transduction system in rat arteries forming the circle of Willis. Endocrinology. 1994; 135:373-378. [PubMed: 8013371]

Cardinali DP, Ladizesky MG, Boggio V, Cutrera RA, Mautalen C. Melatonin effects on bone: experimental facts and clinical perspectives. J Pineal Res. 2003; 34:81-87. [PubMed: 12562498]

Carlberg C, Hooft van Huijsduijnen R, Staple JK, DeLamarter JF, Becker-Andre M. RZRs, a new family of retinoid-related orphan receptors that function as both monomers and homodimers. Mol Endocrinol. 1994; 8:757-770. [PubMed: 7935491]

Carrillo-Vico A, Garcia-Perganeda A, Naji L, Calvo JR, Romero MP, Guerrero JM. Expression of membrane and nuclear melatonin receptor mRNA and protein in the mouse immune system. Cell Mol Life Sci. 2003; 60:2272-2278. [PubMed: 14618273]

Carrillo-Vico A, Guerrero JM, Lardone PJ, Reiter RJ. A review of the multiple actions of melatonin on the immune system. Endocrine. 2005; 27:189-200. [PubMed: 16217132]

Casao A, Mendoza N, Perez-Pe R, Grasa P, Abecia JA, Forcada F, Cebrian-Perez JA, Muino-Blanco T. Melatonin prevents capacitation and apoptotic-like changes of ram spermatozoa and increases fertility rate. J Pineal Res. 2010; 48:39-46. [PubMed: 19919602]

Celinski K, Konturek SJ, Konturek PC, Brzozowski T, Cichoz-Lach H, Slomka M, Malgorzata P, Bielanski W, Reiter RJ. Melatonin or L-tryptophan accelerates healing of gastroduodenal ulcers in patients treated with omeprazole. J Pineal Res. 2011; 50:389-394. [PubMed: 21362032]

Celinski K, Konturek SJ, Konturek PC, Brzozowski T, Cichoz-Lach H, Slomka M, Malgorzata P, Bielanski W, Reiter RJ. Melatonin or L-tryptophan accelerates healing of gastroduodenal ulcers in patients treated with omeprazole. J Pineal Res. 2011; 50:389-394. [PubMed: 21362032]

Chambers JC, Zhang W, Zabaneh D, Sehmi J, Jain P, McCarthy MI, Froguel P, Ruokonen A, Balding D, Jarvelin MR, Scott J, Elliott P, Kooner JS. Common genetic variation near melatonin receptor MTNR1B contributes to raised plasma glucose and increased risk of type 2 diabetes among Indian Asians and European Caucasians. Diabetes. 2009; 58:2703-2708. [PubMed: 19651812]

Chan AS, Lai FP, Lo RK, Voyno-Yasenetskaya TA, Stanbridge EJ, Wong YH. Melatonin mt1 and MT2 receptors stimulate c-Jun N-terminal kinase via pertussis toxin-sensitive and -insensitive $\mathrm{G}$ proteins. Cell Signal. 2002; 14:249-257. [PubMed: 11812653]

Chuffa LG, Seiva FR, Favaro WJ, Teixeira GR, Amorim JP, Mendes LO, Fioruci BA, Pinheiro PF, Fernandes AA, Franci JA, Delella FK, Martinez M, Martinez. Melatonin reduces LH, 17 betaestradiol and induces differential regulation of sex steroid receptors in reproductive tissues during rat ovulation. Reprod Biol Endocrinol. 2011; 9:108. [PubMed: 21810236] 
Cohen M, Lippman M, Chabner B. Role of pineal gland in aetiology and treatment of breast cancer. Lancet. 1978; 2:814-816. [PubMed: 81365]

Cos S, Sánchez-Barceló EJ. Melatonin and mammary pathological growth. Front Neuroendocrinol. 2000; 21:133-170. [PubMed: 10764528]

Cos S, Gonzalez A, Martinez-Campa C, Mediavilla MD, Alonso-Gonzalez C, Sanchez-Barcelo EJ. Estrogen-signaling pathway: a link between breast cancer and melatonin oncostatic actions. Cancer Detect Prev. 2006; 30:118-128. [PubMed: 16647824]

Coto-Montes A, Tomas-Zapico C, Escames G, Leon J, Rodriguez-Colunga MJ, Tolivia D, AcunaCastroviejo D. Specific binding of melatonin to purified cell nuclei from mammary gland of swiss mice: day-night variations and effect of continuous light. J Pineal Res. 2003; 34:297-301. [PubMed: 12662354]

Csaba G, Barath P. Morphological changes of thymus and the thyroid gland after postnatal extirpation of pineal body. Endocrinol Exp. 1975; 9:59-67. [PubMed: 1084274]

Dai J, Ram PT, Yuan L, Spriggs LL, Hill SM. Transcriptional repression of RORalpha activity in human breast cancer cells by melatonin. Mol Cell Endocrinol. 2001; 176:111-120. [PubMed: 11369450]

Danforth DN Jr, Tamarkin L, Lippman ME. Melatonin increases oestrogen receptor binding activity of human breast cancer cells. Nature. 1983; 305:323-325. [PubMed: 6621687]

Dell'anna ML, Picardo M. A review and a new hypothesis for non-immunological pathogenetic mechanisms in vitiligo. Pigment Cell Res. 2006; 19:406- 411. [PubMed: 16965269]

Demas GE, Nelson RJ. Photoperiod and temperature interact to affect immune parameters in adult male deer mice (Peromyscus maniculatus). J Biol Rhythms. 1996; 11:94-102. [PubMed: 8744237]

Doolen S, Krause DN, Dubocovich ML, Duckles SP. Melatonin mediates two distinct responses in vascular smooth muscle. Eur J Pharmacol. 1998; 345:67-69. [PubMed: 9593596]

Drazen DL, Bilu D, Bilbo SD, Nelson RJ. Melatonin enhancement of splenocyte proliferation is attenuated by luzindole, a melatonin receptor antagonist. Am J Physiol Regul Integr Comp Physiol. 2001; 280:R1476-R1482. [PubMed: 11294771]

Drew JE, Williams LM, Hannah LT, Barrett P, Abramovich DR. Melatonin receptors in the human fetal kidney: 2-[ ${ }^{125}$ I] iodomelatonin binding sites correlated with expression of Mella and Mellb receptor genes. J Endocrinol. 1998; 156:261-267. [PubMed: 9518871]

Dubocovich ML. Melatonin receptors: are there multiple subtypes? Trends Pharmacol Sci. 1995; 16:50-56. [PubMed: 7762083]

Dubocovich ML, Markowska M. Functional MT1 and MT2 melatonin receptors in mammals. Endocrine. 2005; 27:101-110. [PubMed: 16217123]

Dubocovich ML, Yun K, Al-Ghoul WM, Benloucif S, Masana MI. Selective MT2 melatonin receptor antagonists block melatonin-mediated phase advances of circadian rhythms. FASEB J. 1998; 12:1211-1220. [PubMed: 9737724]

Dubocovich ML, Rivera-Bermudez MA, Gerdin MJ, Masana MI. Molecular pharmacology, regulation and function of mammalian melatonin receptors. Front Biosci. 2003; 8:d1093-d1108. [PubMed: 12957828]

Dubocovich ML, Hudson RL, Sumaya IC, Masana MI, Manna E. Effect of MT1 melatonin receptor deletion on melatonin-mediated phase shift of circadian rhythms in the C57BL/6 mouse. J Pineal Res. 2005; 39:113-120. [PubMed: 16098087]

Dubocovich ML, Delagrange P, Krause DN, Sugden D, Cardinali DP, Olcese J. International Union of Basic and Clinical Pharmacology. LXXV Nomenclature, classification, and pharmacology of G protein-coupled melatonin receptors. Pharmacol Rev. 2010; 62:343-380. [PubMed: 20605968]

Ducsay CA, Yellon SM. Photoperiod regulation of uterine activity and melatonin rhythms in pregnant rhesus macaque. Biol Reprod. 1991; 44:967-974. [PubMed: 1873397]

Dufourny L, Levasseur A, Migaud M, Callebaut I, Pontarotti P, Malpaux B, Monget P. GPR50 is the mammalian ortholog of Mel1c: evidence of rapid evolution in mammals. BMC Evol Biol. 2008; 8:105. [PubMed: 18400093]

Ebisawa T, Karne S, Lerner MR, Reppert SM. Expression cloning of a high-affinity melatonin receptor from Xenopus dermal melanophores. Proc Natl Acad Sci USA. 1994; 91:6133-6137. [PubMed: 7517042] 
Esposito T, Magliocca S, Formicola D, Gianfrancesco F. piR_015520 belongs to Piwi-associated RNAs regulates expression of the human melatonin receptor 1A gene. PLoS One. 2011; 6:e22727. [PubMed: 21818375]

Esrefoglu M, Seyhan M, Gul M, Parlakpinar H, Batcioglu K, Uyumlu B. Potent therapeutic effect of melatonin on aging skin in pinealectomized rats. J Pineal Res. 2005; 39:231-237. [PubMed: 16150102]

Facciola G, Hidestrand M, von Bahr C, Tybring G. Cytochrome P450 isoforms involved in melatonin metabolism in human liver microsomes. Eur J Clin Pharmacol. 2001; 56:881-888. [PubMed: 11317475]

Ferry G, Hecht S, Berger S, Moulharat N, Coge F, Guillaumet G, Leclerc V, Yous S, Delagrange P, Boutin JA. Old and new inhibitors of quinone reductase 2. Chem Biol Interact. 2010; 186:103109. [PubMed: 20399199]

Figueroa JP, Honnebier MB, Jenkins S, Nathanielsz PW. Alteration of 24-h rhythms in myometrial activity in the chronically catheterized pregnant rhesus monkey after a 6-h shift in the light-dark cycle. Am J Obstet Gynecol. 1990; 163:648-654. [PubMed: 2386157]

Fischer TW, Burmeister G, Schmidt HW, Elsner P. Melatonin increases anagen hair rate in women with androgenetic alopecia or diffuse alopecia: results of a pilot randomized controlled trial. $\mathrm{Br} \mathrm{J}$ Dermatol. 2004; 150:341-345. [PubMed: 14996107]

Fischer TW, Zmijewski MA, Zbytek B, Sweatman TW, Slominski RM, Wortsman J, Slominski A. Oncostatic effects of the indole melatonin and expression of its cytosolic and nuclear receptors in cultured human melanoma cell lines. Int J Oncol. 2006; 29:665-672. [PubMed: 16865283]

Fischer TW, Slominski A, Tobin DJ, Paus R. Melatonin and the hair follicle. J Pineal Res. 2008a; 44:1-15. [PubMed: 18078443]

Fischer TW, Slominski A, Zmijewski MA, Reiter RJ, Paus R. Melatonin as a major skin protectant: from free radical scavenging to DNA damage repair. Exp Dermatol. 2008b; 17:713-730. [PubMed: 18643846]

Galano A, Tan DX, Reiter RJ. Melatonin as a natural ally against oxidative stress: a physicochemical examination. J Pineal Res. 2011; 51:1-16. [PubMed: 21752095]

Ganguly K, Sharma AV, Reiter RJ, Swarnakar S. Melatonin promotes angiogenesis during protection and healing of indomethacin-induced gastric ulcer: role of matrix metaloproteinase-2. J Pineal Res. 2010; 49:130-140. [PubMed: 20492444]

Garcia-Maurino S, Gonzalez-Haba MG, Calvo JR, Rafii-El-Idrissi M, Sanchez-Margalet V, Goberna R, Guerrero JM. Melatonin enhances IL-2, IL-6, and IFN-gamma production by human circulating CD4+ cells: a possible nuclear receptor-mediated mechanism involving T helper type 1 lymphocytes and monocytes. J Immunol. 1997; 159:574-581. [PubMed: 9218571]

Garcia-Maurino S, Pozo D, Calvo JR, Guerrero JM. Correlation between nuclear melatonin receptor expression and enhanced cytokine production in human lymphocytic and monocytic cell lines. J Pineal Res. 2000; 29:129-137. [PubMed: 11034109]

Girgert R, Hanf V, Emons G, Grundker C. Membrane-bound melatonin receptor MT1 down-regulates estrogen responsive genes in breast cancer cells. J Pineal Res. 2009; 47:23-31. [PubMed: 19522736]

Girouard H, Chulak C, Lejossec M, Lamontagne D, de Champlain J. Vasorelaxant effects of the chronic treatment with melatonin on mesenteric artery and aorta of spontaneously hypertensive rats. J Hypertens. 2001; 19:1369-1377. [PubMed: 11518844]

Gomez-Moreno G, Guardia J, Ferrera MJ, Cutando A, Reiter RJ. Melatonin in diseases of the oral cavity. Oral Dis. 2010; 16:242-247. [PubMed: 19682319]

Gorray KC, Quay WB. Effects of pinealectomy and of sham-pinealectomy on blood glucose levels in the alloxan-diabetic rat. Horm Metab Res. 1978; 10:389-392. [PubMed: 711132]

Grace MS, Cahill GM, Besharse JC. Melatonin deacetylation: retinal vertebrate class distribution and Xenopus laevis tissue distribution. Brain Res. 1991; 559:56-63. [PubMed: 1782560]

Guerrero JM, Pozo D, Garcia-Maurino S, Carrillo A, Osuna C, Molinero P, Calvo JR. Nuclear receptors are involved in the enhanced IL-6 production by melatonin in U937 cells. Biol Signals Recept. 2000; 9:197-202. [PubMed: 10899704] 
Hall RA, Premont RT, Lefkowitz RJ. Heptahelical receptor signaling: beyond the G protein paradigm. J Cell Biol. 1999; 145:927-932. [PubMed: 10352011]

Harbert GM, Groft BY, Spisso K. Effect of biorhythms on blood flow distiribution in the pregnant uterus (Macaca mulatta). Am J Obstet Gynecol. 1979; 135:828-839. [PubMed: 116548]

Hardeland R, Poeggeler B. Non-vertebrate melatonin. J Pineal Res. 2003; 34:233-241. [PubMed: 12662344]

Hardeland R, Reiter RJ, Poeggeler B, Tan DX. The significance of the metabolism of the neurohormone melatonin: antioxidative protection and formation of bioactive substances. Neurosci Biobehav Rev. 1993; 17:347-357. [PubMed: 8272286]

Hildebrandt JD. Role of subunit diversity in signaling by heterotrimeric $\mathrm{G}$ proteins. Biochem Pharmacol. 1997; 54:325-339. [PubMed: 9278091]

Hill SM, Cheng C, Yuan L, Mao L, Jockers R, Dauchy B, Frasch T, Blask DE. Declining melatonin levels and MT1 receptor expression in aging rats is associated with enhanced mammary tumor growth and decreased sensitivity to melatonin. Breast Cancer Res Treat. 2010; 127:91-98. [PubMed: 20549340]

Hirata F, Hayaishi O, Tokuyama T, Seno S. In vitro and in vivo formation of two new metabolites of melatonin. J Biol Chem. 1974; 249:1311-1313. [PubMed: 4814344]

Holloway WR, Grota LJ, Brown GM. Determination of immunoreactive melatonin in the colon of the rat by immunocytochemistry. J Histochem Cytochem. 1980; 28:255-262. [PubMed: 6444434]

Holmes SW, Sugden D. Proceedings: the effect of melatonin on pinealectomy-induced hypertension in the rat. Br J Pharmacol. 1976; 56:360P-361P.

Honnebier MBOM, Nathanielsz PW. Primate parturition and the role of the maternal circadian system. Eur J Obstet Gynecol Reprod Biol. 1994; 55:193-203. [PubMed: 7958165]

Honnebier MB, Jenkins SL, Wentworth RA, Figueroa JP, Nathanielsz PW. Temporal structuring of delivery in the absence of a photoperiod: preparturient myometrial activity of the rhesus monkey is related to maternal body temperature and depends on the maternal circadian system. Biol Reprod. 1991; 45:617-625. [PubMed: 1751637]

Houssay AB, Pazo JH, Epper CE. Effects of the pineal gland upon the hair cycles in mice. J Invest Dermatol. 1966; 47:230-234. [PubMed: 5922981]

Huang Z, Wells D. The human oocyte and cumulus cells relationship: new insights from the cumulus cell transcriptome. Mol Hum Reprod. 2010; 16:715-725. [PubMed: 20435609]

Ibraheem M, Galbraith H, Scaife J, Ewen S. Growth of secondary hair follicles of the Cashmere goat in vitro and their response to prolactin and melatonin. J Anat. 1994; 185 (Pt 1):135-142. [PubMed: 7559108]

Iriti M, Varoni EM, Vitalini S. Melatonin in traditional Mediterranean diets. J Pineal Res. 2010; 49:101-105. [PubMed: 20536683]

Iskander K, Paquet M, Brayton C, Jaiswal AK. Deficiency of NRH:quinone oxidoreductase 2 increases susceptibility to 7,12-dimethylbenz(a)anthracene and benzo(a)pyrene-induced skin carcinogenesis. Cancer Res. 2004; 64:5925-5928. [PubMed: 15342368]

Iwasaki S, Nakazawa K, Sakai J, Kometani K, Iwashita M, Yoshimura Y, Maruyama T. Melatonin as a local regulator of human placental function. J Pineal Res. 2005; 39:261-265. [PubMed: 16150106]

Jaworek J, Nawrot-Porabka K, Leja-Szpak A, Bonior J, Szklarczyk J, Kot M, Konturek SJ, Pawlik WW. Melatonin as modulator of pancreatic enzyme secretion and pancreatoprotector. J Physiol Pharmacol. 2007; 58 (Suppl 6):65-80. [PubMed: 18212401]

Jetten AM. Retinoid-related orphan receptors (RORs): critical roles in development, immunity, circadian rhythm, and cellular metabolism. Nucl Recept Signal. 2009; 7:e003. [PubMed: 19381306]

Jockers R, Maurice P, Boutin JA, Delagrange P. Melatonin receptors, heterodimerization, signal transduction and binding sites: what's new? Br J Pharmacol. 2008; 154:1182-1195. [PubMed: 18493248]

Jung-Hynes B, Reiter RJ, Ahmad N. Sirtuins, melatonin and circadian rhythms: building a bridge between aging and cancer. J Pineal Res. 2010; 48:9-19. [PubMed: 20025641] 
Kallen J, Schlaeppi JM, Bitsch F, Delhon I, Fournier B. Crystal structure of the human RORalpha ligand binding domain in complex with cholesterol sulfate at 2.2 A. J Biol Chem. 2004; 279:14033-14038. [PubMed: 14722075]

Kaneko Y, Hayashi T, Yu S, Tajiri N, Bae EC, Solomita MA, Chheda SH, Weinbren NL, Parolini O, Borlongan CV. Human amniotic epithelial cells express melatonin receptor MT1, but not melatonin receptor MT2: a new perspective to neuroprotection. J Pineal Res. 2011; 50:272-280. [PubMed: 21269327]

Kawashima K, Miwa Y, Fujimoto K, Oohata H, Nishino H, Koike H. Antihypertensive action of melatonin in the spontaneously hypertensive rat. Clin Exp Hypertens A. 1987; 9:1121-1131. [PubMed: 3304732]

Kim TH, Jung JA, Kim GD, Jang AH, Ahn HJ, Park YS, Park CS. Melatonin inhibits the development of 2,4-dinitrofluorobenzene-induced atopic dermatitis-like skin lesions in NC/Nga mice. J Pineal Res. 2009; 47:324-329. [PubMed: 19817972]

Kobayashi Y, Itoh MT, Kondo H, Okuma Y, Sato S, Kanishi Y, Hamada N, Kiguchi K, Ishizuka B. Melatonin binding sites in estrogen receptor-positive cells derived from human endometrial cancer. J Pineal Res. 2003; 35:71-74. [PubMed: 12887647]

Kobayashi H, Kromminga A, Dunlop TW, Tychsen B, Conrad F, Suzuki N, Memezawa A, Bettermann A, Aiba S, Carlberg C, Paus R. A role of melatonin in neuroectodermal-mesodermal interactions: the hair follicle synthesizes melatonin and expresses functional melatonin receptors. FASEB J. 2005; 19:1710-1712. [PubMed: 16030176]

Konturek SJ, Konturek PC, Brzozowski T. Melatonin in gastroprotection against stress-induced acute gastric lesions and in healing of chronic gastric ulcers. J Physiol Pharmacol. 2006; 57 (Suppl 5): 51-66.

Konturek SJ, Konturek PC, Brzozowska I, Pawlik M, Sliwowski Z, Czesnikiewicz-Guzik M, Kwiecien S, Brzozowski T, Bubenik GA, Pawlik WW. Localization and biological activities of melatonin in intact and diseased gastrointestinal tract (GIT). J Physiol Pharmacol. 2007a; 58:381-405. [PubMed: 17928638]

Konturek SJ, Konturek PC, Brzozowski T, Bubenik GA. Role of melatonin in upper gastrointestinal tract. J Physiol Pharmacol. 2007b; 58 (Suppl 6):23-52. [PubMed: 18212399]

Konturek PC, Konturek SJ, Burnat G, Brzozowski T, Brzozowska I, Reiter RJ. Dynamic physiological and molecular changes in gastric ulcer healing achieved by melatonin and its precursor Ltryptophan in rats. J Pineal Res. 2008; 45:180-190. [PubMed: 18298459]

Korkmaz A, Topal T, Tan DX, Reiter RJ. Role of melatonin in metabolic regulation. Rev Endocr Metab Disord. 2009; 10:261-270. [PubMed: 19911281]

Koyama H, Nakade O, Takada Y, Kaku T, Lau KH. Melatonin at pharmacologic doses increases bone mass by suppressing resorption through down-regulation of the RANKL-mediated osteoclast formation and activation. J Bone Miner Res. 2002; 17:1219-1229. [PubMed: 12096835]

Krause DN, Barrios VE, Duckles SP. Melatonin receptors mediate potentiation of contractile responses to adrenergic nerve stimulation in rat caudal artery. Eur J Pharmacol. 1995; 276:207213. [PubMed: 7601206]

Kumasaka S, Shimozuma M, Kawamoto T, Mishima K, Tokuyama R, Kamiya Y, Davaadorj P, Saito I, Satomura K. Possible involvement of melatonin in tooth development: expression of melatonin 1a receptor in human and mouse tooth germs. Histochem Cell Biol. 2010; 133:577-584. [PubMed: 20372918]

Lai L, Yuan L, Chen Q, Dong C, Mao L, Rowan B, Frasch T, Hill SM. The Galphai and Galphaq proteins mediate the effects of melatonin on steroid/thyroid hormone receptor transcriptional activity and breast cancer cell proliferation. J Pineal Res. 2008; 45:476-488. [PubMed: 18705646]

Lai L, Yuan L, Cheng Q, Dong C, Mao L, Hill SM. Alteration of the MT1 melatonin receptor gene and its expression in primary human breast tumors and breast cancer cell lines. Breast Cancer Res Treat. 2009; 118:293-305. [PubMed: 18979234]

Lang U, Aubert ML, Conne BS, Bradtke JC, Sizonenko PC. Influence of exogenous melatonin on melatonin secretion and the neuroendocrine reproductive axis of intact male rats during sexual maturation. Endocrinology. 1983; 112:1578-1584. [PubMed: 6299701] 
Lanoix D, Ouellette R, Vaillancourt C. Expression of melatoninergic receptors in human placental choriocarcinoma cell lines. Hum Reprod. 2006; 21:1981-1989. [PubMed: 16632463]

Lanoix D, Beghdadi H, Lafond J, Vaillancourt C. Human placental trophoblasts synthesize melatonin and express its receptors. J Pineal Res. 2008; 45:50-60. [PubMed: 18312298]

Lanoix D, Lacasse AA, Reiter RJ, Vaillancourt C. Melatonin: the smart killer. The human trophoblast as a model. Mol Cell Endocrinol. 2012; 348:1-11. [PubMed: 21889572]

Lee CK, Kang HS, Lee BJ, Kang HM, Choi WS, Kang SG. Effects of dopamine and melatonin on the regulation of the PIT-1 isotype, placental growth hormone and lactogen gene expressions in the rat placenta. Mol Cells. 1999; 9:646-651. [PubMed: 10672932]

Lee CK, Moon DH, Shin CS, Kim H, Yoon YD, Kang HS, Lee BJ, Kang SG. Circadian expression of Mel1a and PL-II genes in placenta: effects of melatonin on the PL-II gene expression in the rat placenta. Mol Cell Endocrinol. 2003; 200:57-66. [PubMed: 12644299]

Leja-Szpak A, Jaworek J, Pierzchalski P, Reiter RJ. Melatonin induces pro-apoptotic signaling pathway in human pancreatic carcinoma cells (PANC-1). J Pineal Res. 2010; 49:248-255. [PubMed: 20626591]

Lerner AB. Hormonal control of pigmentation. Annu Rev Med. 1960; 11:187-194. [PubMed: 14415937]

Lerner AB, Case JD, Mori W, Wright MR. Melatonin in peripheral nerve. Nature. 1959; 183:1821. [PubMed: 14415934]

Lerner AB, Case JD, Takahashi Y. Isolation of melatonin and 5-methoxyindole-3-acetic acid from bovine pineal glands. J Biol Chem. 1960; 235:1992-1997. [PubMed: 14415935]

Levoye A, Dam J, Ayoub MA, Guillaume JL, Couturier C, Delagrange P, Jockers R. The orphan GPR50 receptor specifically inhibits MT1 melatonin receptor function through heterodimerization. EMBO J. 2006a; 25:3012-3023. [PubMed: 16778767]

Levoye A, Jockers R, Ayoub MA, Delagrange P, Savaskan E, Guillaume JL. Are G protein-coupled receptor heterodimers of physiological relevance? Focus on melatonin receptors. Chronobiol Int. 2006b; 23:419-426. [PubMed: 16687315]

Li C, Shi Y, You L, Wang L, Chen ZJ. Association of rs10830963 and rs10830962 SNPs in the melatonin receptor (MTNR1B) gene among Han Chinese women with polycystic ovary syndrome. Mol Hum Reprod. 2011; 17:193-198. [PubMed: 20959387]

Lima FB, Machado UF, Bartol I, Seraphim PM, Sumida DH, Moraes SM, Hell NS, Okamoto MM, Saad MJ, Carvalho CR, Cipolla-Neto J. Pinealectomy causes glucose intolerance and decreases adipose cell responsiveness to insulin in rats. Am J Physiol. 1998; 275:E934-E941. [PubMed: 9843734]

Lindström V, Enetronth P, Swahn ML. Diurnal variation of uterine contractility. Br J Obstetr Gynaecol. 1984; 91:155-159.

Liu T, Borjigin J. $N$-Acetyltransferase is not the rate-limiting enzyme of melatonin synthesis at night. J Pineal Res. 2005; 39:91-96. [PubMed: 15978063]

Lopez-Gonzalez MA, Calvo JR, Osuna C, Guerrero JM. Interaction of melatonin with human lymphocytes: evidence for binding sites coupled to potentiation of cyclic AMP stimulated by vasoactive intestinal peptide and activation of cyclic GMP. J Pineal Res. 1992; 12:97-104. [PubMed: 1324307]

Lotufo CM, Lopes C, Dubocovich ML, Farsky SH, Markus RP. Melatonin and $N$-acetylserotonin inhibit leukocyte rolling and adhesion to rat microcirculation. Eur J Pharmacol. 2001; 430:351357. [PubMed: 11711054]

Lovenberg W, Weissbach H, Udenfriend S. Aromatic L-amino acid decarboxylase. J Biol Chem. 1962; 237:89-93. [PubMed: 14466899]

Lovenberg W, Jequier E, Sjoerdsma A. Tryptophan hydroxylation: measurement in pineal gland, brainstem, and carcinoid tumor. Science. 1967; 155:217-219. [PubMed: 6015530]

Lusardi P, Preti P, Savino S, Piazza E, Zoppi A, Fogari R. Effect of bedtime melatonin ingestion on blood pressure of normotensive subjects. Blood Press Monit. 1997; 2:99-103. [PubMed: 10234100] 
Lusardi P, Piazza E, Fogari R. Cardiovascular effects of melatonin in hypertensive patients well controlled by nifedipine: a 24-h study. Br J Clin Pharmacol. 2000; 49:423-427. [PubMed: 10792199]

Ma X, Idle JR, Krausz KW, Gonzalez FJ. Metabolism of melatonin by human cytochromes p450. Drug Metab Dispos. 2005; 33:489-494. [PubMed: 15616152]

Maestroni GJ, Conti A, Pierpaoli W. Role of the pineal gland in immunity. Circadian synthesis and release of melatonin modulates the antibody response and antagonizes the immunosuppressive effect of corticosterone. J Neuroimmunol. 1986; 13:19-30. [PubMed: 2944914]

Maestroni GJ, Conti A, Pierpaoli W. Role of the pineal gland in immunity. III Melatonin antagonizes the immunosuppressive effect of acute stress via an opiatergic mechanism. Immunology. 1988; 63:465-469. [PubMed: 3350581]

Mahmoud I, Salman SS, Al-Khateeb A. Continuous darkness and continuous light induce structural changes in the rat thymus. J Anat. 1994; 185 (Pt 1):143-149. [PubMed: 7559109]

Man GC, Wong JH, Wang WW, Sun GQ, Yeung BH, Ng TB, Lee SK, Ng BK, Qiu Y, Cheng JC. Abnormal melatonin receptor $1 \mathrm{~B}$ expression in osteoblasts from girls with adolescent idiopathic scoliosis. J Pineal Res. 2011; 50:395-402. [PubMed: 21480980]

Mao L, Yuan L, Slakey LM, Jones FE, Burow ME, Hill SM. Inhibition of breast cancer cell invasion by melatonin is mediated through regulation of the $\mathrm{p} 38$ mitogen-activated protein kinase signaling pathway. Breast Cancer Res. 2010; 12:R107. [PubMed: 21167057]

Masana MI, Doolen S, Ersahin C, Al-Ghoul WM, Duckles SP, Dubocovich ML, Krause DN. MT(2) melatonin receptors are present and functional in rat caudal artery. J Pharmacol Exp Ther. 2002; 302:1295-1302. [PubMed: 12183692]

McIsaac WM, Page IH. The metabolism of serotonin (5-hydroxytryptamine). J Biol Chem. 1959; 234:858-864. [PubMed: 13654278]

Menendez-Pelaez A, Poeggeler B, Reiter RJ, Barlow-Walden L, Pablos MI, Tan DX. Nuclear localization of melatonin in different mammalian tissues: immunocytochemical and radioimmunoassay evidence. J Cell Biochem. 1993; 53:373-382. [PubMed: 8300754]

Morgan PJ, Lawson W, Davidson G, Howell HE. Guanine nucleotides regulate the affinity of melatonin receptors on the ovine pars tuberalis. Neuroendocrinology. 1989; 50:359-362. [PubMed: 2552345]

Morgan MA, Silavin SL, Wentworth RA, Figueroa JP, Honnebier MBOM, Fishburne JI Jr, Nathanielsz PW. Different patterns of myometrial activity and 24-h rhythms in myometrial contractility in the gravid baboon during the second half of pregnancy. Biol Reprod. 1992; 46:1158-1164. [PubMed: 1391314]

Muhlbauer E, Peschke E. Evidence for the expression of both the MT1- and in addition, the MT2melatonin receptor, in the rat pancreas, islet and beta-cell. J Pineal Res. 2007; 42:105-106. [PubMed: 17198545]

Myers DA, Nathanielsz PWR. Biological basis of term and preterm labor. Clin Perinatol. 1993:20.

Nathanielsz PW. A time to be born: implications of animal studies in maternal-fetal medicine. Birth. 1994:21.

Nava M, Romero F, Quiroz Y, Parra G, Bonet L, Rodriguez-Iturbe B. Melatonin attenuates acute renal failure and oxidative stress induced by mercuric chloride in rats. Am J Physiol Renal Physiol. 2000; 279:F910-F918. [PubMed: 11053052]

Navajas C, Kokkola T, Poso A, Honka N, Gynther J, Laitinen JT. A rhodopsin-based model for melatonin recognition at its $G$ protein-coupled receptor. Eur J Pharmacol. 1996; 304:173-183. [PubMed: 8813600]

Nelson RJ, Demas GE. Role of melatonin in mediating seasonal energetic and immunologic adaptations. Brain Res Bull. 1997; 44:423-430. [PubMed: 9370207]

Nelson CS, Marino JL, Allen CN. Melatonin receptors activate heteromeric G-protein coupled Kir3 channels. NeuroReport. 1996; 7:717-720. [PubMed: 8733729]

Niles LP, Wang J, Shen L, Lobb DK, Younglai EV. Melatonin receptor mRNA expression in human granulosa cells. Mol Cell Endocrinol. 1999; 156:107-110. [PubMed: 10612428] 
Nosjean O, Ferro M, Coge F, Beauverger P, Henlin JM, Lefoulon F, Fauchere JL, Delagrange P, Canet $\mathrm{E}$, Boutin JA. Identification of the melatonin-binding site MT3 as the quinone reductase 2. J Biol Chem. 2000; 275:31311-31317. [PubMed: 10913150]

Nosjean O, Nicolas JP, Klupsch F, Delagrange P, Canet E, Boutin JA. Comparative pharmacological studies of melatonin receptors: MT1, MT2 and MT3/QR2. Tissue distribution of MT3/QR2. Biochem Pharmacol. 2001; 61:1369-1379. [PubMed: 11331072]

Olcese J. Circadian aspects of mammalian parturition: a review. Mol Cell Endocrinol. 2011; 349:6267. [PubMed: 21777654]

Pandi-Perumal SR, Trakht I, Srinivasan V, Spence DW, Maestroni GJ, Zisapel N, Cardinali DP. Physiological effects of melatonin: role of melatonin receptors and signal transduction pathways. Prog Neurobiol. 2008; 85:335-353. [PubMed: 18571301]

Panduro-Baron G, Gonzales-Moreno J, Hernandez-Figuerolla E. The biorhythm of birth. Int J Gynecol Obstet. 1994; 45:283-284.

Pang, SF.; Tang, PL.; Tang, GWK.; Yam, WC., editors. Melatonin and Pregnancy. Pergamon Press; Oxford: 1985.

Paradies G, Petrosillo G, Paradies V, Reiter RJ, Ruggiero FM. Melatonin, cardiolipin and mitochondrial bioenergetics in health and disease. J Pineal Res. 2010; 48:297-310. [PubMed: 20433638]

Paul P, Lahaye C, Delagrange P, Nicolas JP, Canet E, Boutin JA. Characterization of 2$\left[{ }^{125}\right.$ I] iodomelatonin binding sites in Syrian hamster peripheral organs. J Pharmacol Exp Ther. 1999; 290:334-340. [PubMed: 10381796]

Paulis L, Pechanova O, Zicha J, Barta A, Gardlik R, Celec P, Kunes J, Simko F. Melatonin interactions with blood pressure and vascular function during L-NAME-induced hypertension. J Pineal Res. 2010; 48:102-108. [PubMed: 20041987]

Peschke E. Melatonin, endocrine pancreas and diabetes. J Pineal Res. 2008; 44:26- 40. [PubMed: 18078445]

Peschke E, Fauteck JD, Musshoff U, Schmidt F, Beckmann A, Peschke D. Evidence for a melatonin receptor within pancreatic islets of neonate rats: functional, autoradiographic, and molecular investigations. J Pineal Res. 2000; 28:156-164. [PubMed: 10739302]

Picinato MC, Hirata AE, Cipolla-Neto J, Curi R, Carvalho CR, Anhe GF, Carpinelli AR. Activation of insulin and IGF-1 signaling pathways by melatonin through MT1 receptor in isolated rat pancreatic islets. J Pineal Res. 2008; 44:88-94. [PubMed: 18078453]

Pintor J, Martin L, Pelaez T, Hoyle CH, Peral A. Involvement of melatonin MT(3) receptors in the regulation of intraocular pressure in rabbits. Eur J Pharmacol. 2001; 416:251-254. [PubMed: 11290376]

Pozo D, Delgado M, Fernandez-Santos JM, Calvo JR, Gomariz RP, Martin-Lacave I, Ortiz GG, Guerrero JM. Expression of the Mel1a-melatonin receptor mRNA in T and B subsets of lymphocytes from rat thymus and spleen. FASEB J. 1997; 11:466-473. [PubMed: 9194527]

Quastel MR, Rahamimoff R. Effect of melatonin on spontaneous contractions and response to 5hydroxytryptamine of rat isolated duodenum. Br J Pharmacol Chemother. 1965; 24:455-461. [PubMed: 14320859]

Quiroz Y, Ferrebuz A, Romero F, Vaziri ND, Rodriguez-Iturbe B. Melatonin ameliorates oxidative stress, inflammation, proteinuria, and progression of renal damage in rats with renal mass reduction. Am J Physiol Renal Physiol. 2008; 294:F336-F344. [PubMed: 18077597]

Ram PT, Dai J, Yuan L, Dong C, Kiefer TL, Lai L, Hill SM. Involvement of the mt1 melatonin receptor in human breast cancer. Cancer Lett. 2002; 179:141-150. [PubMed: 11888668]

Ramracheya RD, Muller DS, Squires PE, Brereton H, Sugden D, Huang GC, Amiel SA, Jones PM, Persaud SJ. Function and expression of melatonin receptors on human pancreatic islets. J Pineal Res. 2008; 44:273-279. [PubMed: 18194202]

Rasmussen BM, Christiansen C, Rasmussen OW, Hansen C, Hermansen K. Alcohol and postexercise metabolic responses in type 2 diabetes. Metabolism. 1999; 48:597-602. [PubMed: 10337860]

Recio J, Mediavilla MD, Cardinali DP, Sanchez-Barcelo EJ. Pharmacological profile and diurnal rhythmicity of 2-[ $\left.{ }^{125} \mathrm{I}\right]$-iodomelatonin binding sites in murine mammary tissue. J Pineal Res. 1994; 16:10-17. [PubMed: 8158518] 
Reiter R. Melatonin: that ubiquitously acting pineal hormone. Physiology. 1991a; 6:223-227.

Reiter RJ. Melatonin: the chemical expression of darkness. Mol Cell Endocrinol. 1991b; 79:C153C158. [PubMed: 1936532]

Reiter RJ. Pineal melatonin: cell biology of its synthesis and of its physiological interactions. Endocr Rev. 1991c; 12:151-180. [PubMed: 1649044]

Reiter RJ. The melatonin rhythm: both a clock and a calendar. Experientia. 1993; 49:654-664. [PubMed: 8395408]

Reiter RJ, Tan DX, Qi W, Manchester LC, Karbownik M, Calvo JR. Pharmacology and physiology of melatonin in the reduction of oxidative stress in vivo. Biol Signals Recept. 2000; 9:160-171. [PubMed: 10899701]

Reiter RJ, Tan DX, Manchester LC, Pilar Terron M, Flores LJ, Koppisepi S. Medical implications of melatonin: receptor-mediated and receptor-independent actions. Adv Med Sci. 2007; 52:11-28. [PubMed: 18217386]

Reiter RJ, Tan DX, Fuentes-Broto L. Melatonin: a multitasking molecule. Prog Brain Res. 2010; 181:127-151. [PubMed: 20478436]

Reppert SM, Weaver DR, Ebisawa T. Cloning and characterization of a mammalian melatonin receptor that mediates reproductive and circadian responses. Neuron. 1994; 13:1177-1185. [PubMed: 7946354]

Reppert SM, Godson C, Mahle CD, Weaver DR, Slaugenhaupt SA, Gusella JF. Molecular characterization of a second melatonin receptor expressed in human retina and brain: the Mel1b melatonin receptor. Proc Natl Acad Sci USA. 1995; 92:8734-8738. [PubMed: 7568007]

Reppert SM, Weaver DR, Ebisawa T, Mahle CD, Kolakowski LF Jr. Cloning of a melatonin-related receptor from human pituitary. FEBS Lett. 1996a; 386:219-224. [PubMed: 8647286]

Reppert SM, Weaver DR, Godson C. Melatonin receptors step into the light: cloning and classification of subtypes. Trends Pharmacol Sci. 1996b; 17:100-102. [PubMed: 8936344]

Richter HG, Torres-Farfan C, Garcia-Sesnich J, Abarzua-Catalan L, Henriquez MG, Alvarez-Felmer M, Gaete F, Rehren GE, Seron-Ferre M. Rhythmic expression of functional MT1 melatonin receptors in the rat adrenal gland. Endocrinology. 2008; 149:995-1003. [PubMed: 18039783]

Roca AL, Godson C, Weaver DR, Reppert SM. Structure, characterization, and expression of the gene encoding the mouse Mel1a melatonin receptor. Endocrinology. 1996; 137:3469-3477. [PubMed: 8754776]

Rodriguez C, Mayo JC, Sainz RM, Antolin I, Herrera F, Martin V, Reiter RJ. Regulation of antioxidant enzymes: a significant role for melatonin. J Pineal Res. 2004; 36:1-9. [PubMed: 14675124]

Rogawski MA, Roth RH, Aghajanian GK. Melatonin: deacetylation to 5-methoxytryptamine by liver but not brain aryl acylamidase. J Neurochem. 1979; 32:1219-1226. [PubMed: 285213]

Rogelsperger O, Wlcek K, Ekmekcioglu C, Humpeler S, Svoboda M, Konigsberg R, Klimpfinger M, Jager W, Thalhammer T. Melatonin receptors, melatonin metabolizing enzymes and cyclin D1 in human breast cancer. J Recept Signal Transduct Res. 2011; 31:180-187. [PubMed: 21385053]

Ronnberg L, Kauppila A, Leppaluoto J, Martikainen H, Vakkuri O. Circadian and seasonal variation in human preovulatory follicular fluid melatonin concentration. J Clin Endocrinol Metab. 1990; 71:492-496. [PubMed: 2380343]

Roth JA, Kim BG, Lin WL, Cho MI. Melatonin promotes osteoblast differentiation and bone formation. J Biol Chem. 1999; 274:22041-22047. [PubMed: 10419530]

Roy D, Belsham DD. Melatonin receptor activation regulates $\mathrm{GnRH}$ gene expression and secretion in GT1-7 GnRH neurons. Signal transduction mechanisms. J Biol Chem. 2002; 277:251-258. [PubMed: 11684691]

Roy D, Angelini NL, Fujieda H, Brown GM, Belsham DD. Cyclical regulation of GnRH gene expression in GT1-7 GnRH-secreting neurons by melatonin. Endocrinology. 2001; 142:47114720. [PubMed: 11606436]

Sadowsky DW, Yellon S, Mitchell MD, Nathanielsz PW. Lack of effect of melatonin on myometrial electromyographic activity in the pregnant sheep at 138-142 days gestation (term $=147$ days gestation). Endocrinology. 1991; 128:1812- 1818. [PubMed: 1900777] 
Sandyk R, Anastasiadis PG, Anninos PA, Tsagas N. Is the pineal gland involved in the pathogenesis of endometrial carcinoma. Int J Neurosci. 1992; 62:89-96. [PubMed: 1342018]

Schaeffer HJ, Sirotkin AV. Melatonin and serotonin directly regulate oxytocin, insulin-like growth factor-I and progesterone secretion by cultured human granulosa cells. Adv Exp Med Biol. 1995; 395:547-548. [PubMed: 8714015]

Schaeffer HJ, Sirotkin AV. Melatonin and serotonin regulate the release of insulin-like growth factor-I, oxytocin and progesterone by cultured human granulosa cells. Exp Clin Endocrinol Diabetes. 1997; 105:109-112. [PubMed: 9137942]

Schallreuter KU, Wood JM, Pittelkow MR, Gutlich M, Lemke KR, Rodl W, Swanson NN, Hitzemann $\mathrm{K}$, Ziegler I. Regulation of melanin biosynthesis in the human epidermis by tetrahydrobiopterin. Science. 1994; 263:1444-1446. [PubMed: 8128228]

Schallreuter KU, Bahadoran P, Picardo M, Slominski A, Elassiuty YE, Kemp EH, Giachino C, Liu JB, Luiten RM, Lambe T, Le Poole IC, Dammak I, Onay H, Zmijewski MA, Dell' Anna ML, Zeegers MP, Cornall RJ, Paus R, Ortonne JP, Westerhof W. Vitiligo pathogenesis: autoimmune disease, genetic defect, excessive reactive oxygen species, calcium imbalance, or what else? Exp Dermatol. 2008; 17:139-140. (discussion 141-160). [PubMed: 18205713]

Schlabritz-Loutsevitch N, Hellner N, Middendorf R, Muller D, Olcese J. The human myometrium as a target for melatonin. J Clin Endocrinol Metab. 2003; 88:908-913. [PubMed: 12574232]

Semak I, Naumova M, Korik E, Terekhovich V, Wortsman J, Slominski A. A novel metabolic pathway of melatonin: oxidation by cytochrome $C$. Biochemistry. 2005; 44:9300-9307. [PubMed: 15981996]

Semak I, Korik E, Antonova M, Wortsman J, Slominski A. Metabolism of melatonin by cytochrome P450s in rat liver mitochondria and microsomes. J Pineal Res. 2008; 45:515-523. [PubMed: 18717775]

Seron-Ferre M, Ducsay C, Valenzuela GJ. Circadian rhythms during pregnancy. Endocr Rev. 1993; 4:594-608. [PubMed: 8262008]

Sjoblom M, Safsten B, Flemstrom G. Melatonin-induced calcium signaling in clusters of human and rat duodenal enterocytes. Am J Physiol Gastrointest Liver Physiol. 2003; 284:G1034-G1044. [PubMed: 12584110]

Slominski A, Pruski D. Melatonin inhibits proliferation and melanogenesis in rodent melanoma cells. Exp Cell Res. 1993; 206:189-294. [PubMed: 8500544]

Slominski A, Paus R, Bomirski A. Hypothesis: possible role for the melatonin receptor in vitiligo: discussion paper. J R Soc Med. 1989; 82:539-541. [PubMed: 2552111]

Slominski A, Chassalevris N, Mazurkiewicz J, Maurer M, Paus R. Murine skin as a target for melatonin bioregulation. Exp Dermatol. 1994; 3:45-50. [PubMed: 8061934]

Slominski A, Pisarchik A, Semak I, Sweatman T, Wortsman J. Characterization of the serotoninergic system in the C57BL/6 mouse skin. Eur J Biochem. 2003; 270:3335-3344. [PubMed: 12899690]

Slominski A, Pisarchik A, Wortsman J. Expression of genes coding melatonin and serotonin receptors in rodent skin. Biochim Biophys Acta. 2004a; 1680:67-70. [PubMed: 15488986]

Slominski A, Tobin DJ, Shibahara S, Wortsman J. Melanin pigmentation in mammalian skin and its hormonal regulation. Physiol Rev. 2004b; 84:1155-1228. [PubMed: 15383650]

Slominski A, Fischer TW, Zmijewski MA, Wortsman J, Semak I, Zbytek B, Slominski RM, Tobin DJ. On the role of melatonin in skin physiology and pathology. Endocrine. 2005a; 27:137-148. [PubMed: 16217127]

Slominski A, Wortsman J, Plonka PM, Schallreuter KU, Paus R, Tobin DJ. Hair follicle pigmentation. J Invest Dermatol. 2005b; 124:13-21. [PubMed: 15654948]

Slominski A, Wortsman J, Tobin DJ. The cutaneous serotoninergic/melatoninergic system: securing a place under the sun. FASEB J. 2005c; 19:176-194. [PubMed: 15677341]

Slominski A, Tobin DJ, Zmijewski MA, Wortsman J, Paus R. Melatonin in the skin: synthesis, metabolism and functions. Trends Endocrinol Metab. 2008; 19:17-24. [PubMed: 18155917]

Smirnov AN. Nuclear melatonin receptors. Biochemistry (Moscow). 2001; 66:19- 26. [PubMed: 11240388] 
Soares JM Jr, Masana MI, Ersahin C, Dubocovich ML. Functional melatonin receptors in rat ovaries at various stages of the estrous cycle. J Pharmacol Exp Ther. 2003; 306:694-702. [PubMed: 12721330]

Song Y, Ayre EA, Pang SF. The identification and characterization of ${ }^{125}$ I-labelled iodomelatoninbinding sites in the duck kidney. J Endocrinol. 1992; 135:353-359. [PubMed: 1474342]

Song Y, Chan CW, Brown GM, Pang SF, Silverman M. Studies of the renal action of melatonin: evidence that the effects are mediated by $37 \mathrm{kDa}$ receptors of the Mel1a subtype localized primarily to the basolateral membrane of the proximal tubule. FASEB J. 1997; 11:93-100. [PubMed: 9034171]

Stehle JH, Saade A, Rawashdeh O, Ackermann K, Jilg A, Sebesteny T, Maronde E. A survey of molecular details in the human pineal gland in the light of phylogeny, structure, function and chronobiological diseases. J Pineal Res. 2011; 51:17-43. [PubMed: 21517957]

Steinhilber D, Brungs M, Werz O, Wiesenberg I, Danielsson C, Kahlen JP, Nayeri S, Schrader M, Carlberg C. The nuclear receptor for melatonin represses 5-lipoxygenase gene expression in human B lymphocytes. J Biol Chem. 1995; 270:7037-7040. [PubMed: 7706239]

Suzuki N, Somei M, Kitamura K, Reiter RJ, Hattori A. Novel bromomelatonin derivatives suppress osteoclastic activity and increase osteoblastic activity: implications for the treatment of bone diseases. J Pineal Res. 2008; 44:326-334. [PubMed: 18339128]

Taketani T, Tamura H, Takasaki A, Lee L, Kizuka F, Tamura I, Taniguchi K, Maekawa R, Asada H, Shimamura K, Reiter RJ, Sugino N. Protective role of melatonin in progesterone production by human luteal cells. J Pineal Res. 2011; 51:207-213. [PubMed: 21585519]

Tamura H, Nakamura Y, Terron MP, Flores LJ, Manchester LC, Tan DX, Sugino N, Reiter RJ. Melatonin and pregnancy in the human. Reprod Toxicol. 2008; 25:291-303. [PubMed: 18485664]

Tamura H, Nakamura Y, Korkmaz A, Manchester LC, Tan DX, Sugino N, Reiter RJ. Melatonin and the ovary: physiological and pathophysiological implications. Fertil Steril. 2009; 92:328-343. [PubMed: 18804205]

Tan DX, Poeggeler B, Reiter RJ, Chen LD, Chen S, Manchester LC, Barlow-Walden LR. The pineal hormone melatonin inhibits DNA-adduct formation induced by the chemical carcinogen safrole in vivo. Cancer Lett. 1993; 70:65-71. [PubMed: 8330303]

Tan DX, Manchester LC, Reiter RJ, Qi W, Kim SJ, El-Sokkary GH. Ischemia/reperfusion-induced arrhythmias in the isolated rat heart: prevention by melatonin. J Pineal Res. 1998; 25:184-191. [PubMed: 9745988]

Tan DX, Manchester LC, Reiter RJ, Qi WB, Karbownik M, Calvo JR. Significance of melatonin in antioxidative defense system: reactions and products. Biol Signals Recept. 2000; 9:137-159. [PubMed: 10899700]

Tan DX, Manchester LC, Burkhardt S, Sainz RM, Mayo JC, Kohen R, Shohami E, Huo YS, Hardeland R, Reiter RJ. N1-acetyl-N2-formyl-5-methoxykynuramine, a biogenic amine and melatonin metabolite, functions as a potent antioxidant. FASEB J. 2001; 15:2294-2296. [PubMed: 11511530]

Tan DX, Manchester LC, Hardeland R, Lopez-Burillo S, Mayo JC, Sainz RM, Reiter RJ. Melatonin: a hormone, a tissue factor, an autocoid, a paracoid, and an antioxidant vitamin. J Pineal Res. 2003; 34:75-78. [PubMed: 12485375]

Tan DX, Manchester LC, Terron MP, Flores LJ, Reiter RJ. One molecule, many derivatives: a neverending interaction of melatonin with reactive oxygen and nitrogen species? J Pineal Res. 2007; 42:28-42. [PubMed: 17198536]

Tan DX, Manchester LC, Fuentes-Broto L, Paredes SD, Reiter RJ. Significance and application of melatonin in the regulation of brown adipose tissue metabolism: relation to human obesity. Obes Rev. 2011; 12:167-188. [PubMed: 20557470]

Tengattini S, Reiter RJ, Tan DX, Terron MP, Rodella LF, Rezzani R. Cardiovascular diseases: protective effects of melatonin. J Pineal Res. 2008; 44:16-25. [PubMed: 18078444]

Thor PJ, Krolczyk G, Gil K, Zurowski D, Nowak L. Melatonin and serotonin effects on gastrointestinal motility. J Physiol Pharmacol. 2007; 58 (Suppl 6):97-103. [PubMed: 18212403] 
Ting KN, Dunn WR, Davies DJ, Sugden D, Delagrange P, Guardiola-Lemaitre B, Scalbert E, Wilson VG. Studies on the vasoconstrictor action of melatonin and putative melatonin receptor ligands in the tail artery of juvenile Wistar rats. Br J Pharmacol. 1997; 122:1299-1306. [PubMed: 9421275]

Toma CD, Svoboda M, Arrich F, Ekmekcioglu C, Assadian O, Thalhammer T. Expression of the melatonin receptor (MT) 1 in benign and malignant human bone tumors. J Pineal Res. 2007; 43:206-213. [PubMed: 17645699]

Torres-Farfan C, Richter HG, Rojas-Garcia P, Vergara M, Forcelledo ML, Valladares LE, Torrealba F, Valenzuela GJ, Seron-Ferre M. mt1 Melatonin receptor in the primate adrenal gland: inhibition of adrenocorticotropin-stimulated cortisol production by melatonin. J Clin Endocrinol Metab. 2003; 88:450-458. [PubMed: 12519889]

Torres-Farfan C, Richter HG, Germain AM, Valenzuela GJ, Campino C, Rojas-Garcia P, Forcelledo ML, Torrealba F, Seron-Ferre M. Maternal melatonin selectively inhibits cortisol production in the primate fetal adrenal gland. J Physiol. 2004; 554:841-856. [PubMed: 14673186]

Treeck O, Haldar C, Ortmann O. Antiestrogens modulate MT1 melatonin receptor expression in breast and ovarian cancer cell lines. Oncol Rep. 2006; 15:231-235. [PubMed: 16328061]

Vanecek J, Vollrath L. Developmental changes and daily rhythm in melatonin-induced inhibition of 3', 5'-cyclic AMP accumulation in the rat pituitary. Endocrinology. 1990; 126:1509-1513. [PubMed: 2155103]

Vaughan MK, Reiter RJ. Transient hypertrophy of the ventral prostate and coagulating glands and accelerated thymic involution following pinealectomy in the mouse. Tex Rep Biol Med. 1971; 29:579-586. [PubMed: 4113015]

Vincent L, Cohen W, Delagrange P, Boutin JA, Nosjean O. Molecular and cellular pharmacological properties of 5-methoxycarbonylamino- $N$-acetyltryptamine (MCA-NAT): a nonspecific MT3 ligand. J Pineal Res. 2010; 48:222-229. [PubMed: 20210850]

Viswanathan M, Laitinen JT, Saavedra JM. Expression of melatonin receptors in arteries involved in thermoregulation. Proc Natl Acad Sci USA. 1990; 87:6200-6203. [PubMed: 2166949]

Vriend J, Lauber JK. Letter: effects of light intensity, wavelength and quanta on gonads and spleen of the deer mouse. Nature. 1973; 244:37-38. [PubMed: 4582483]

Webley GE, Luck MR. Melatonin directly stimulates the secretion of progesterone by human and bovine granulosa cells in vitro. J Reprod Fertil. 1986; 78:711-717. [PubMed: 3806524]

Webley GE, Luck MR, Hearn JP. Stimulation of progesterone secretion by cultured human granulosa cells with melatonin and catecholamines. J Reprod Fertil. 1988; 84:669-677. [PubMed: 3199386]

Weissbach A. A novel system for the incorporation of amino acids by extracts of E. coli B. Biochim. Biophys Acta. 1960; 41:498-509.

Wiesenberg I, Missbach M, Kahlen JP, Schrader M, Carlberg C. Transcriptional activation of the nuclear receptor RZR alpha by the pineal gland hormone melatonin and identification of CGP 52608 as a synthetic ligand. Nucleic Acids Res. 1995; 23:327-333. [PubMed: 7885826]

Witt-Enderby PA, Bennett J, Jarzynka MJ, Firestine S, Melan MA. Melatonin receptors and their regulation: biochemical and structural mechanisms. Life Sci. 2003; 72:2183-2198. [PubMed: 12628439]

Woo MM, Tai CJ, Kang SK, Nathwani PS, Pang SF, Leung PC. Direct action of melatonin in human granulosa-luteal cells. J Clin Endocrinol Metab. 2001; 86:4789-4797. [PubMed: 11600542]

Yie SM, Niles LP, Younglai EV. Melatonin receptors on human granulosa cell membranes. J Clin Endocrinol Metab. 1995; 80:1747-1749. [PubMed: 7745030]

Yu HS, Hernandez V, Haywood M, Wong CG. Melatonin inhibits the proliferation of retinal pigment epithelial (RPE) cells in vitro. In Vitro Cell Dev Biol Anim. 1993; 29A:415-418. [PubMed: 8390974]

Zanoboni A, Zanoboni-Muciaccia W. Experimental hypertension in pinealectomized rats. Life Sci. 1967; 6:2327-2331. [PubMed: 6060280]

Zhao H, Pang SF, Poon AM. Variations of mt1 melatonin receptor density in the rat uterus during decidualization, the estrous cycle and in response to exogenous steroid treatment. J Pineal Res. 2002; 33:140-145. [PubMed: 12220327] 


\section{Highlights}

- Melatonin is produced in mammals, plants, unicellular eukaryotes, and bacteria.

- It acts as neurotransmitter, hormone, cytokine, metabolic modulator and antioxidant.

- Melatonin regulates functions of peripheral organs.

- Melatonin activates membrane bound or nuclear receptors. 

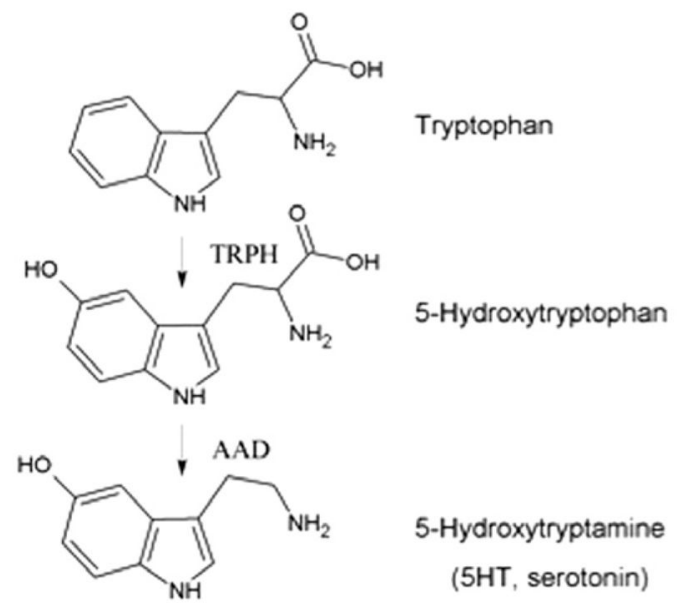

5-Hydroxytryptamine
(5HT, serotonin)
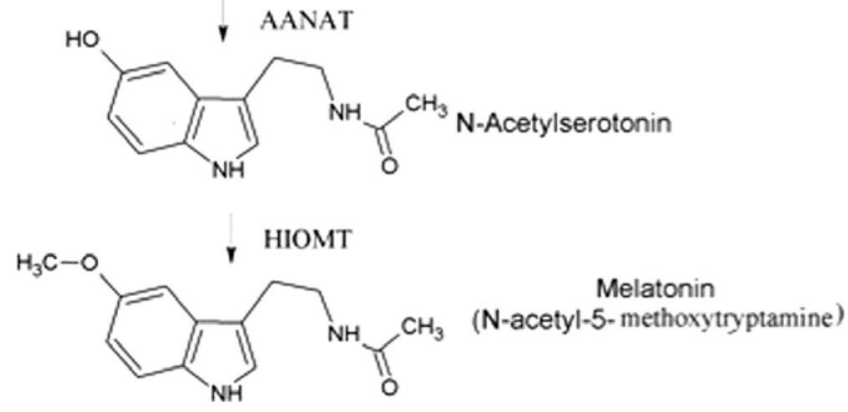

Fig. 1.

The biosynthetic pathway of melatonin. Melatonin is synthesized from tryptophan in a multistep process. The final two synthetic steps mediated by AANAT and HIOMT are considered to be rate limiting. TRPH: tryptophan hydroxylase, AAD: aromatic amino acid decarboxylase, AANAT: arylalkylamine $N$-acetyltransferase, HIOMT: hydroxyindole- $O$ methyl transferase. 


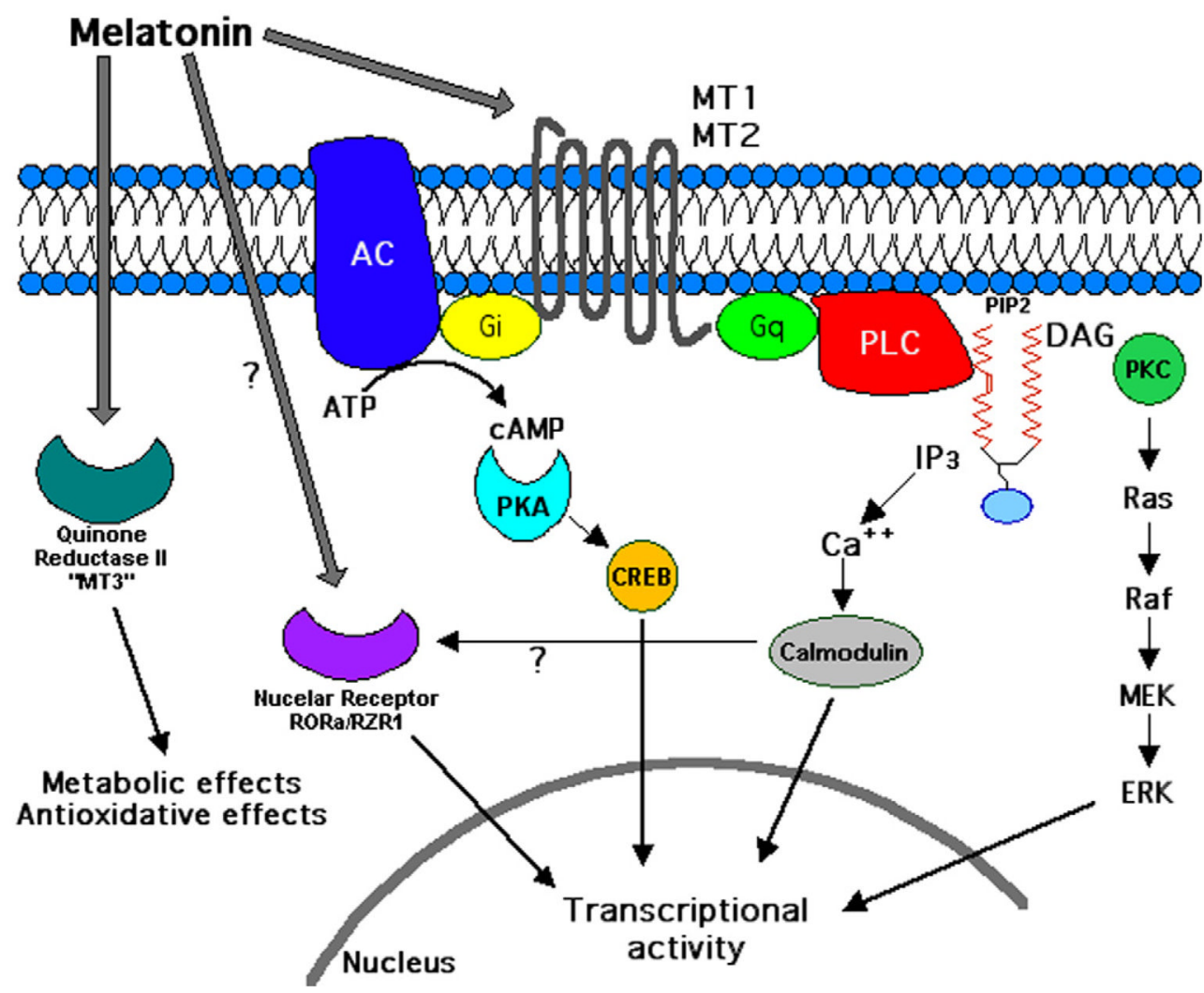

Fig. 2.

Signaling schematic of melatonin receptor subtypes. Melatonin exerts many of its biological actions through MT1 or MT2 membrane receptors (G protein-coupled) or, according to some authors, via nuclear receptors (RORa/RZR1). Signaling pathways known to be activated by melatonin receptors are shown. Quinone reductase II ("MT3" receptors) have been demonstrated only in hamster and rabbit. 
Table 1

Tissue distribution of melatonin receptors.

\begin{tabular}{lll}
\hline Tissues & Melatonin receptors expressed & Role of melatonin \\
\hline SCN & MT2 & Regulate circadian rhythm \\
Retina & MT2, ROR $\alpha$ & Decrease dopamine release \\
Vasculature & MT1, MT2 & $\begin{array}{l}\text { MT1: vasoconstrictor } \\
\text { MT2: vasodilator }\end{array}$ \\
Immune system & MT1, MT2, ROR $\alpha$ & $\begin{array}{l}\text { Inhibit leukotriene rolling } \\
\text { Promote immune cell proliferation } \\
\text { Stimulates IL2 and IL6 production }\end{array}$ \\
Reproducive system & MT1, MT2 & Decreases GnRH, LH, FSH release \\
Pancreas & MT1, MT2, ROR $\alpha$ & Decrease insulin release \\
Skin & MT1, MT2, ROR $\alpha$ & Regulate hair growth, and functions of epidermis \\
GI tract & MT1, MT2 & Decrease gastric contraction, peristalsis, and sertonin's actions \\
& & Increases bicarbonate, amylase, and CCK release \\
Bone & MT1, ROR $\alpha$ & Increases osteoblastic activity and decrease osteoclastic activity \\
Kidneys & MT1, MT2 & Protects from inflammation, regulate glomerular filtration \\
Placenta & MT1, MT2, ROR $\alpha$ & ROS scavenger, decrease apoptosis \\
Uterus & MT1, MT2 & Myometrial contractility \\
Endometrium & MT1, MT2 & Trophoblast invasion in early pregnancy \\
\hline
\end{tabular}

